\title{
Advantageous characteristics of the diatom Chaetoceros gracilis as a sustainable biofuel producer
}

Hiromi Tokushima', Natsuko Inoue-Kashino ${ }^{1}$, Yukine Nakazato ${ }^{1}$, Atsunori Masuda ${ }^{1,2,3}$, Kentaro Ifuku ${ }^{4}$ and Yasuhiro Kashino ${ }^{1 *}$ (D)

\begin{abstract}
Background: Diatoms have attracted interest as biofuel producers. Here, the contents of lipids and photosynthetic pigments were analyzed in a marine centric diatom, Chaetoceros gracilis. This diatom can be genetically engineered using our previously reported transformation technique and has a potential to produce valuable materials photosynthetically. Sustainable culture conditions for cost-effective production of biological materials under autotrophic conditions with atmospheric carbon dioxide were investigated in the laboratory. A large-scale, open-air culture was also performed.

Results: Cell population doubling time was $\sim 10 \mathrm{~h}$ under continuous illumination without $\mathrm{CO}_{2}$ enrichment, and large amounts of triacylglycerols (TAG) and fucoxanthin accumulated under a wide range of salinity and nutrient conditions, reaching $\sim 200$ and $18.5 \mathrm{mg} / \mathrm{L}$, respectively. It was also shown that C. gracilis produced high amounts of TAG without the need for nitrogen or silica deprivation, which is frequently imposed to induce lipid production in many other microalgae. Furthermore, C. gracilis was confirmed to be highly tolerant to changes in environmental conditions, such as salinity. The diatom grew well and produced abundant lipids when using sewage water or liquid fertilizer derived from cattle feces without augmented carbon dioxide. High growth rates (doubling time $<20 \mathrm{~h}$ ) were obtained in a large-scale, open-air culture, in which light irradiance and temperature fluctuated and were largely different from laboratory conditions.
\end{abstract}

Conclusions: The ability of this microalga to accumulate TAG without nutrient deprivation, which incurs added labor, high costs, and complicates scalability, is important for low-cost industrial applications. Furthermore, its high tolerance to changes in environmental conditions and high growth rates observed in large-scale, open-air culture implied scalability of this diatom for industrial applications. Therefore, C. gracilis would have great potential as a biofactory.

Keywords: Chaetoceros gracilis, Diatom, Biofuel, Lipid, Triacylglycerols, Fucoxanthin, EPA, Chlorophyll

\section{Background}

Diatoms emerged on our planet $\sim 150$ million years ago $[1,2]$, and they are considered one of the major sources of crude oil [3-5]. Currently, diatoms are responsible for nearly one-quarter of the annual global photosynthetic production of organic matter, which is nearly equal to

\footnotetext{
*Correspondence: kashino@sci.u-hyogo.ac.jp

1 Graduate School of Life Science, University of Hyogo, 3-2-1 Koto,

Kamigori, Ako-gun, Hyogo 678-1297, Japan

Full list of author information is available at the end of the article
}

the proportion attributed to tropical rain forests $[6,7]$. In many diatomaceous species, assimilated carbon is accumulated in cells as triacylglycerol (TAG) that accounts for $25-45 \%$ of their cell dry weight $[8,9]$, while their silica shell makes up $40-78 \%$ of their weight [10]. In addition, diatoms contain many types of fatty acids (FAs) and related organic molecules [11]. As a result, diatoms have attracted interest as biofuel producers. Currently, among the 20,000-200,000 species of diatoms, only a few have been studied as potential biofuel producers [12-14], including Phaeodactylum tricornutum, Thalassiosira 
pseudonana, Thalassiosira weissflogii, Cyclotella cryptica [9], Fistulifera solaris [15], Chaetoceros gracilis (C. muelleri) [16, 17], Cylindrotheca spp., and Nitzschia spp. [8]. In laboratory-scale experiments, nitrogen or silica deprivation is frequently used to induce lipid production and accumulation [8, 17-23].

In addition to organic precursors for biofuels, valuable metabolites, such as eicosapentaenoic acid (EPA) and docosahexaenoic acid (DHA) [24], as well as photosynthetic pigments, such as fucoxanthin, diadinoxanthin, diatoxanthin, and chlorophylls (Chl) $a$ and $c$ [25-27], are found in diatoms. EPA, DHA, and fucoxanthin are also clinically important [24, 28-33]. Fucoxanthin is a major pigment in diatoms and some types of haptophytes [34-36] as well as brown algae [37], and its function is to harvest light energy by associating with fucoxanthinchlorophyll binding protein [38]. Fucoxanthin's inhibitory effects on cancer cells [28-33] and its antioxidant effects [37] have attracted attention regarding its potential use as a potent drug and dietary supplement similar to astaxanthin [39]. Chl $c$ is a photosynthetic pigment possessed by brown-colored photosynthetic organisms, such as diatoms and brown algae. In contrast to regular Chls that belong to the chlorin family of compounds, $\mathrm{C} 17$ and $\mathrm{C} 18$ in pyrrole ring $\mathrm{D}$ of $\mathrm{Chl} c$ are connected by a double bond. Therefore, Chl $c$ belongs to the porphyrin family of compounds [40]. Until now, three types of Chl $c$ are known, namely $\mathrm{Chl} c_{1}, c_{2}$, and $c_{3}$ [41-43]. Among them, $\mathrm{Chl} c_{1}$ and $c_{2}$ are found in most diatoms. Chl $c_{3}$ is a haptophyte marker pigment [36] and possessed by some diatoms, such as Nitzschia bilobata [42]. An esterified form of Chl $c$ is also known in haptophytes [44-47]. Diadinoxanthin and diatoxanthin are the pigments involved in the diadinoxanthin cycle [34, 48-53], a xanthophyll cycle variant in diatoms [54]. Diadinoxanthin is converted into diatoxanthin under high light conditions to protect photosystems through nonphotochemical quenching. When grown under high light, the diadinoxanthin cycle pigment content usually increases [34, 48-53].

It is desirable to raise the yield of these valuable metabolites through efficient diatom photosynthesis and growth. In this context, genetic manipulation techniques [55-61] are crucial for converting diatoms into "biofactories," and it has been demonstrated that metabolic pathways can be modified using such techniques [62]. For example, knockdown of a multifunctional lipase/phospholipase/acyltransferase causes increased lipid yields in the marine centric diatom T. pseudonana [63]. In P. tricornutum, malic enzyme overexpression enhances total lipid production up to 2.5 -fold without sacrificing growth rate [64]. The transformation efficiency of $P$. tricornutum was considerably improved in our recent work [65]. Genomic analyses of T. pseudonana [66], P. tricornutum
[67], and the oleaginous diatom $F$. solaris [15] have supported the advancement of diatom genetic manipulation, and will facilitate industrial applications of these organisms.

Diatoms are attracting increasing attention as biofactories for the production of many kinds of metabolites. However, large-scale cultivation-a prerequisite for industrial application-has not been successful for most phytoplankton, including diatoms. The limited number of successful examples includes Chlorella, Hematococcus, Euglena, and Spirulina species, which are mainly used for production of dietary supplements or cosmetic ingredients. Although successful large-scale cultivation of these species is advantageous for industrial production, there are no established techniques for genetic transformation of these microalgae.

In nature, diatoms sometimes grow in dense accumulations called "spring blooms" [26, 68], which can be detected by satellite [69]. Thus, large-scale diatom cultivation at a high density is feasible. Currently, large-scale diatom cultivation is only performed for feed production, such as for shrimp larviculture in southeastern Asia [70] and clam larviculture in Japan [71]. Among thousands of diatom species, the marine centric diatom $C$. gracilis is considered an ideal species for shrimp larviculture owing to its nutritional content and size as well as its ability to be cultivated on an industrial scale [70]. There is also existing knowledge of its physiological characteristics regarding photosynthesis and oil production [34, 38, 72, $73]$. Furthermore, we recently established a stable and efficient genetic transformation technique for $C$. gracilis [74]. Therefore, C. gracilis appears to be a good candidate for balancing high growth rate with high metabolite yield. In this work, C. gracilis' growth rate and its yield of several metabolites were investigated to demonstrate that $C$. gracilis is a promising species as a biofactory to produce beneficial metabolites, including potential drug candidates. The effects of changes in environmental conditions, such as nutrient availability, were also assessed in terms of facilitating the production of these materials at a reasonable cost.

\section{Results}

\section{Effects of vitamins on growth}

F/2 medium and Daigo IMK medium, which differs from $\mathrm{F} / 2$ medium mainly in nitrate concentration (200 vs. $75 \mathrm{ppm}$ in $\mathrm{F} / 2$ ), contain vitamins, including vitamin $\mathrm{B}_{12}$. The effects of vitamin deprivation on $C$. gracilis growth were assessed using $F / 2$-enriched seawater made with sea salts (hereafter "seawater"). The possible effects of preculture history, with or without vitamins, were excluded by subculturing cells at least twice in the same medium with or without vitamins; each subculture was incubated 
for $\sim 1$ week. Cells in vitamin-deficient medium (Fig. 1a, open symbols) grew at almost the same doubling time (DT), $12.0 \mathrm{~h}$, as cells in vitamin-containing medium (Fig. 1a, closed symbols; DT, $10.7 \mathrm{~h}$ ). When cells were subcultured during stationary phase, growth rate was somewhat lower than when subcultured during logarithmic phase (Fig. 1a; Table 1). Cell density and triacylglycerols (TAG) produced after 10 days of culture were not affected by eliminating vitamins from the culture medium (Table 1).

The same experiment was performed with the model diatom P. tricornutum (Fig. 1b; Table 1). This diatom's growth rate was lower than that of $C$. gracilis in $\mathrm{F} / 2$ enriched seawater with vitamins (DT, 14.5 vs. $10.7 \mathrm{~h}$, respectively). When $P$. tricornutum cells were subcultured during logarithmic phase, growth rate and TAG production were not affected by eliminating vitamins. However, when cells were subcultured during stationary phase without vitamins, growth rate and TAG production were reduced. Note that, when cells were subcultured

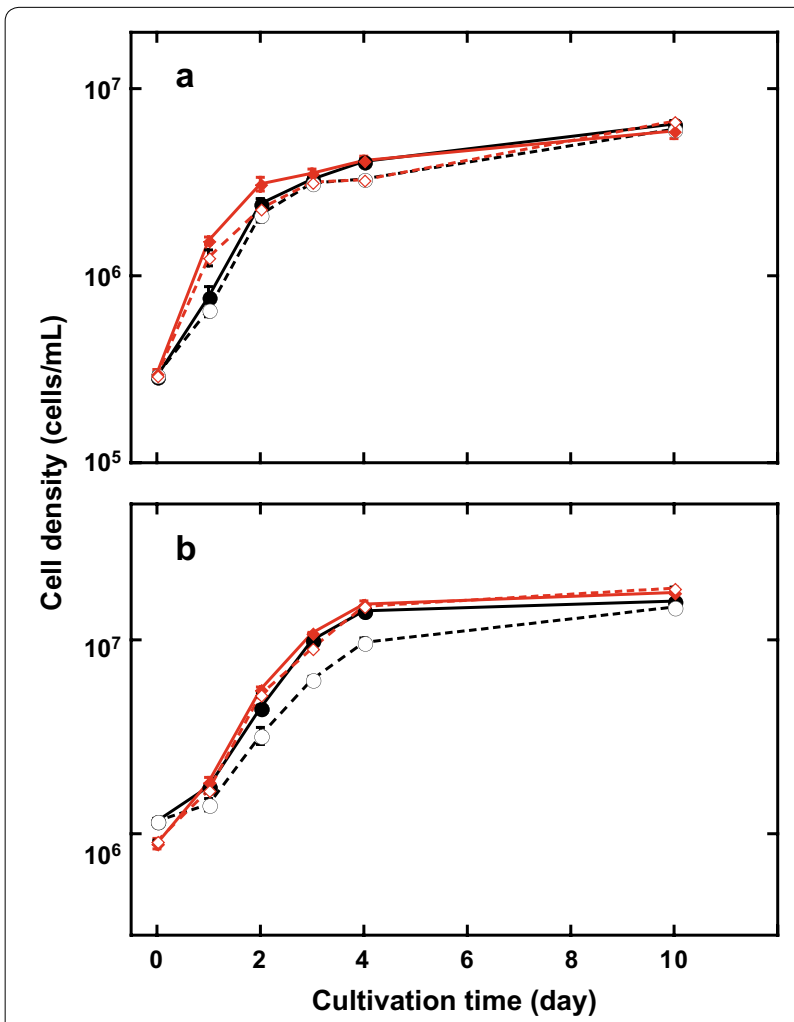

Fig. 1 Growth of C. gracilis (a) and P. tricornutum (b) with or without vitamins. Cells precultured in same culture medium at least twice, then inoculated into fresh medium at logarithmic or stationary phase (red or black lines, respectively) at an $\mathrm{OD}_{730}$ of $\sim 0.07$; cells cultivated at room temperature with photon irradiance of $50 \mu \mathrm{mol}$ photons $\mathrm{m}^{-2} \mathrm{~s}^{-1}$ in F/2-enriched seawater with (closed symbols and solid lines) or without (open symbols and dashed lines) vitamins; and ambient air bubbled through media at stationary phase, cell density was much higher for $P$. tricornutum than for C. gracilis, but the total TAG was much lower in P. tricornutum than in C. gracilis.

\section{Effects of salinity on growth}

Chaetoceros gracilis cells were cultivated in different seawater dilutions. Sea salts were usually used at a concentration of $4 \%(\mathrm{w} / \mathrm{v})$. When sea salt concentrations were reduced to 2 or $3 \%(\mathrm{w} / \mathrm{v})$, growth rate, cell density at the 4th and 10th days of cultivation, and TAG content of C. gracilis were not affected (Table 2). When C. gracilis was grown in $1 \%$ sea salt medium, growth rate was slightly reduced (DT, $12.4 \mathrm{~h}$ ) but TAG production notably increased (Table 2).

Because small decreases in sea salt concentration did not appear to affect $C$. gracilis growth, the effects of salinity on growth were assessed. Base culture media were prepared by varying the $\mathrm{NaCl}$ concentration and supplementing with $\mathrm{MgSO}_{4}, \mathrm{CaCl}_{2}, \mathrm{KCl}$, and $\mathrm{NaHCO}_{3}$ to obtain concentrations roughly equivalent to those in seawater. With salinity similar to the $3 \% \mathrm{NaCl}(\mathrm{w} / \mathrm{v})$ in natural seawater, C. gracilis growth characteristics (Table 3) were similar to those in normal culture medium composed of sea salts and F/2 (Fig. 1; Table 1). When the $\mathrm{NaCl}$ concentration was increased from 3 to $4 \%$, growth rate was decreased and TAG production reduced to less than half the previous rates. Conversely, as described above, when C. gracilis was grown at $\mathrm{NaCl}$ concentrations below $3 \%$, growth characteristics improved. The highest growth rate, cell density, and TAG production were observed when cells were grown in $1 \% \mathrm{NaCl}$ medium. Interestingly, these cells grew well even without $\mathrm{NaCl}$; growth rate and TAG production were higher with $0 \% \mathrm{NaCl}$ than with $4 \%$, even though $C$. gracilis is a marine diatom. However, when C. gracilis cells grown in $3 \% \mathrm{NaCl}$ medium were transferred to $0 \% \mathrm{NaCl}$ conditions, a large proportion of these cells did not survive and the remaining cells began to proliferate after about 1 day.

Growth characteristics at various salinities were different for $P$. tricornutum compared with $C$. gracilis (Table 3). Growth rate and total TAG content of $P$. tricornutum were relatively constant despite changes in $\mathrm{NaCl}$ concentration from 1 to $4 \%$. These results were generally inferior to those of C. gracilis.

\section{Use of urea instead of nitrate as a nitrogen source}

In general, nitrate is the most expensive nutrient for phytoplankton culture and thus the effects of substituting urea for nitrate were assessed (Table 4). In F/2enriched seawater, $C$. gracilis grew much faster with urea than nitrate (DTs, 8.9 and $10.3 \mathrm{~h}$, respectively), and TAG production and cell density were higher with urea than nitrate. When cells were grown with urea in 
Table 1 Effects of vitamins on growth and TAG content of two diatoms, C. gracilis and $P$. tricornutum

\begin{tabular}{|c|c|c|c|c|}
\hline & \multicolumn{2}{|c|}{ Inoculation at logarithmic phase } & \multicolumn{2}{|c|}{ Inoculation at stationary phase } \\
\hline & + vitamins & - vitamins & + vitamins & - vitamins \\
\hline \multicolumn{5}{|l|}{ C. gracilis } \\
\hline Doubling time (h) & $10.7 \pm 0.6$ & $12.0 \pm 0.6$ & $12.6 \pm 0.6$ & $12.5 \pm 0.3$ \\
\hline Cell density on 4th day ( $10^{6}$ cells $/ \mathrm{mL}$ ) & $4.14 \pm 0.22$ & $3.26 \pm 0.07$ & $4.08 \pm 0.15$ & $3.30 \pm 0.07$ \\
\hline Cell density on 10 th day $\left(10^{6}\right.$ cells $/ \mathrm{mL}$ ) & $6.28 \pm 0.25$ & $6.68 \pm 0.04$ & $6.48 \pm 0.27$ & $6.08 \pm 0.19$ \\
\hline Volume-specific TAG on 10th day (mg/L) & $232 \pm 9$ & $190 \pm 5$ & $216 \pm 9$ & $209 \pm 3$ \\
\hline Cell-specific TAG on 10th day (pg/cell) & $38.5 \pm 1.1$ & $29.0 \pm 0.2$ & $33.3 \pm 0.1$ & $34.4 \pm 0.8$ \\
\hline \multicolumn{5}{|l|}{ P. tricornutum } \\
\hline Doubling time (h) & $14.5 \pm 0.1$ & $14.4 \pm 0.2$ & $17.5 \pm 0.8$ & $20.1 \pm 0.9$ \\
\hline Cell density on 4 th day $\left(10^{6}\right.$ cells $\left./ \mathrm{mL}\right)$ & $15.3 \pm 0.6$ & $14.9 \pm 0.2$ & $14.1 \pm 0.2$ & $9.68 \pm 0.52$ \\
\hline Cell density on 10 th day $\left(10^{6}\right.$ cells $\left./ \mathrm{mL}\right)$ & $17.5 \pm 0.3$ & $18.4 \pm 0.3$ & $15.8 \pm 0.2$ & $14.7 \pm 0.6$ \\
\hline Volume-specific TAG on 10th day (mg/L) & $179 \pm 4$ & $181 \pm 5$ & $152 \pm 6$ & $54.5 \pm 5.4$ \\
\hline Cell-specific TAG on 10th day (pg/cell) & $10.2 \pm 0.3)$ & $9.84 \pm 0.20)$ & $9.92 \pm 0.67$ & $3.69 \pm 0.20$ \\
\hline
\end{tabular}

Cells cultivated in $\mathrm{F} / 2$-enriched seawater with or without vitamins ( $\mathrm{B}_{12}$, biotin, and thiamine- $\mathrm{HCl}$ ), and $n=3-4$

Table 2 Effects of diluting seawater on growth and TAG content of C. gracilis

\begin{tabular}{|c|c|c|c|c|}
\hline & \multicolumn{4}{|c|}{ Concentration of sea salts (\%) } \\
\hline & 1 & 2 & 3 & 4 \\
\hline Doubling time (h) & $12.4 \pm 3.1$ & $10.0 \pm 0.6$ & $10.2 \pm 0.2$ & $10.5 \pm 0.8$ \\
\hline Cell density on 4 th day $\left(10^{6}\right.$ cells $\left./ \mathrm{mL}\right)$ & $4.73 \pm 0.23$ & $5.66 \pm 0.20$ & $6.09 \pm 0.27$ & $6.16 \pm 0.24$ \\
\hline Cell density on 10 th day $\left(10^{6}\right.$ cells $\left./ \mathrm{mL}\right)$ & $6.34 \pm 0.25$ & $6.35 \pm 0.33$ & $7.24 \pm 0.28$ & $6.40 \pm 0.65$ \\
\hline Volume-specific TAG on 10th day (mg/L) & $227 \pm 14$ & $194 \pm 16$ & $196 \pm 26$ & $189 \pm 23$ \\
\hline Cell-specific TAG on 10th day (pg/cell) & $35.4 \pm 1.1$ & $35.0 \pm 3.0$ & $30.7 \pm 3.0$ & $33.2 \pm 3.2$ \\
\hline
\end{tabular}

Cells cultivated in various concentrations of seawater made from sea salts, seawater enriched with $\mathrm{F} / 2$ medium without vitamins, and $n=3-4$

Table 3 Effects of salinity on growth and TAG content of two diatoms, C. gracilis and $P$. tricornutum

\begin{tabular}{|c|c|c|c|c|c|c|}
\hline & \multicolumn{6}{|c|}{ Concentration of $\mathrm{NaCl}(\%)$} \\
\hline & 0 & 0.5 & 1 & 2 & 3 & 4 \\
\hline \multicolumn{7}{|l|}{ C. gracilis } \\
\hline Doubling time (h) & $11.1 \pm 0.5$ & $9.52 \pm 0.48$ & $9.16 \pm 0.17$ & $9.75 \pm 0.20$ & $11.3 \pm 1.5$ & $15.7 \pm 0.4$ \\
\hline Cell density on 4th day $\left(10^{6}\right.$ cells $\left./ \mathrm{mL}\right)$ & $2.41 \pm 0.19$ & $4.41 \pm 0.67$ & $5.32 \pm 0.14$ & $5.24 \pm 0.26$ & $3.64 \pm 0.80$ & $2.24 \pm 0.81$ \\
\hline Cell density on 10 th day $\left(10^{6} \text { cells } / \mathrm{mL}\right)^{\mathrm{a}}$ & $3.89 \pm 0.45$ & $5.30 \pm 0.15$ & $6.29 \pm 0.31$ & $6.47 \pm 0.43$ & $3.63 \pm 0.32$ & $2.71 \pm 0.23$ \\
\hline Volume-specific TAG on 10th day (mg/L) & $223 \pm 18$ & $234 \pm 43$ & $272 \pm 4$ & $223 \pm 6$ & $172 \pm 3$ & $69.3 \pm 28.6$ \\
\hline Cell-specific TAG on 10th day (pg/cell) ${ }^{a}$ & $73.1 \pm 7.3$ & $46.2 \pm 4.9$ & $47.0 \pm 2.5$ & $35.5 \pm 3.9$ & $25.5 \pm 0.6$ & $19.3 \pm 5.0$ \\
\hline \multicolumn{7}{|l|}{ P. tricornutum } \\
\hline Doubling time (h) & n.d. & n.d. & $14.6 \pm 0.2$ & $15.8 \pm 0.4$ & $15.4 \pm 0.7$ & $19.0 \pm 0.9$ \\
\hline Cell density on 4th day $\left(10^{6}\right.$ cells $\left./ \mathrm{mL}\right)$ & n.d. & n.d. & $14.9 \pm 0.4$ & $15.4 \pm 0.2$ & $13.2 \pm 0.6$ & $11.6 \pm 0.3$ \\
\hline Cell density on 10 th day $\left(10^{6}\right.$ cells $/ \mathrm{mL}$ ) & n.d. & n.d. & $16.4 \pm 1.0$ & $16.6 \pm 9.2$ & $14.9 \pm 0.1$ & $13.8 \pm 0.6$ \\
\hline Volume-specific TAG on 10th day (mg/L) & n.d. & n.d. & $183 \pm 11$ & $180 \pm 9$ & $158 \pm 14$ & $161 \pm 15$ \\
\hline Cell-specific TAG on 10th day (pg/cell) & n.d. & n.d. & $11.2 \pm 0.4$ & $10.9 \pm 1.1$ & $10.6 \pm 0.8$ & $11.7 \pm 0.6$ \\
\hline
\end{tabular}

Cells cultivated in media containing various $\mathrm{NaCl}$ concentrations; media enriched with $\mathrm{F} / 2$ without vitamins and $\mathrm{MgSO}_{4}, \mathrm{CaCl}_{2}, \mathrm{KCl}$, and $\mathrm{NaHCO}_{3}$ added, as described in "Methods" section

n.d. not determined; $n=3-4$

a $n=2$ 
Table 4 Effects of urea on growth and TAG content of C. gracilis

\begin{tabular}{|c|c|c|c|c|c|c|c|c|}
\hline & \multicolumn{3}{|l|}{ Seawater } & \multicolumn{2}{|l|}{ Marine Art } & \multicolumn{3}{|c|}{$1 \% \mathrm{NaCl}-$ based media } \\
\hline & $F / 2$ & Urea-F/2 & $\begin{array}{l}\mathrm{F} / 2+70 \mathrm{ppm} \\
\text { urea }\end{array}$ & IMK & $\begin{array}{l}\mathrm{IMK}+70 \mathrm{ppm} \\
\text { urea }\end{array}$ & $F / 2$ & Urea-F/2 & $\mathrm{F} / 2+70 \mathrm{ppm}$ urea \\
\hline Doubling time (h) & $10.3 \pm 0.1$ & $8.93 \pm 0.10$ & $10.5 \pm 0.1$ & $10.2 \pm 0.4$ & $8.61 \pm 0.25$ & $9.16 \pm 0.17$ & $9.28 \pm 0.16$ & $9.63 \pm 0.40$ \\
\hline $\begin{array}{l}\text { Cell density on } 4 \text { th } \\
\text { day }\left(10^{6} \text { cells/ }\right. \\
\mathrm{mL})\end{array}$ & $4.72 \pm 0.05$ & $6.01 \pm 0.16$ & $6.36 \pm 0.06$ & $5.22 \pm 0.22$ & $5.67 \pm 0.02$ & $5.37 \pm 0.37$ & $5.36 \pm 0.13$ & $5.52 \pm 0.10$ \\
\hline $\begin{array}{l}\text { Cell density on } \\
10 \text { th day }\left(10^{6}\right. \\
\text { cells } / \mathrm{mL})\end{array}$ & $6.64 \pm 0.01$ & $7.04 \pm 0.02$ & $8.31 \pm 0.18$ & $6.73 \pm 0.14$ & $6.19 \pm 0.05$ & $6.59 \pm 0.34$ & $5.51 \pm 0.22$ & $7.08 \pm 0.13$ \\
\hline $\begin{array}{l}\text { Volume-specific } \\
\text { TAG on } 10 \text { th day } \\
\text { (mg/L) }\end{array}$ & $163 \pm 3$ & $179 \pm 9$ & $150 \pm 6$ & $87.6 \pm 5.3$ & $76.6 \pm 5.0$ & $272 \pm 4$ & $260 \pm 6$ & $159 \pm 15$ \\
\hline $\begin{array}{l}\text { Cell-specific TAG } \\
\text { on 10th day (pg/ } \\
\text { cell) }\end{array}$ & $24.1 \pm 0.8$ & $26.7 \pm 2.6$ & $18.0 \pm 0.5$ & $13.8 \pm 1.1$ & $11.9 \pm 0.9$ & $25.7 \pm 1.9$ & $47.4 \pm 2.4$ & $21.1 \pm 2.1$ \\
\hline
\end{tabular}

Cells cultivated in media enriched with $\mathrm{F} / 2$ without vitamins; urea- $\mathrm{F} / 2$ medium contained urea not nitrate at same molar concentration; $\mathrm{F} / 2+70$ ppm urea and $\mathrm{IMK}+70 \mathrm{ppm}$ urea media contained urea in addition to nitrate; $1 \% \mathrm{NaCl}$-based medium in place of seawater contained $1 \% \mathrm{NaCl}_{\text {and }} \mathrm{MgSO}_{4}, \mathrm{CaCl}_{2}, \mathrm{KCl}$ and $\mathrm{NaHCO}_{3}$ added, as described in "Methods" section; and $n=3$

$1 \%$ NaCl-based medium, no effects on growth or TAG production were observed. When $70 \mathrm{ppm}$ urea was present in the medium along with nitrate, growth and TAG accumulation were slightly suppressed. When $70 \mathrm{ppm}$ urea was added to artificial seawater (Marine Art SF-1) enriched with Daigo IMK medium, growth was accelerated, but TAG production was slightly reduced.

\section{Use of sewage water as a nutrient source}

Because C. gracilis can grow well in various salinities, cells were grown in artificial seawater diluted with sewage water (Table 5). When cells grown in F/2-enriched artificial seawater without vitamins were subcultured (1st subculture) in seawater diluted with the same volume of sewage water ( $50 \%$ by vol), growth and TAG production were slightly reduced compared with values observed with $\mathrm{F} / 2$-enriched artificial seawater. When seawater diluted with two volumes of sewage water ( $67 \%$ by vol) was used, growth rate of the 1st subculture was further reduced (DT, 12.9 and $15.4 \mathrm{~h}$ in 50 and $67 \%$ sewage water, respectively), but total TAG remained almost the same.
Water quality analysis showed that the phosphate concentration in sewage water obtained from Harima Kogen Higashi Waterworks was comparable to that in F/2 and Daigo IMK media (Table 6). The nitrate concentration was much lower in sewage water than in F/2 and Daigo IMK media, and similar values are found in urban sewage treatment plants. Nitrate was a relatively rich nitrogen source for diatom growth in F/2 and Daigo IMK media. In this case, phosphate and silicon were consumed faster than nitrate when cells were grown in F/2 medium (Fig. 2), resulting in lack of growth after day 4 (Fig. 1). This might have been the reason why $C$. gracilis grew and accumulated TAG in sewage water, despite sewage water's apparently poor nutrient content. However, when cells were subcultured again (2nd subculture, Table 5) in the same sewage water culture medium, subsequent growth was reduced, which might have resulted from low phosphate content in sewage water culture media made by mixing sewage water with seawater containing no phosphate. The final phosphate concentration should be 2.0 and $2.7 \mathrm{ppm}$ in 50 and $67 \%$ sewage water culture media, respectively,

Table 5 Use of sewage water as the nutrient source in culture media

\begin{tabular}{|c|c|c|c|c|}
\hline & \multicolumn{2}{|c|}{$50 \%$ sewage water } & \multicolumn{2}{|c|}{$67 \%$ sewage water } \\
\hline & 1st subculture & 2nd subculture & 1st subculture & 2nd subculture \\
\hline Doubling time (h) & $12.9 \pm 0.4$ & $19.2 \pm 0.5$ & $15.4 \pm 0.5$ & $18.3 \pm 0.1$ \\
\hline Cell density on 4 th day $\left(10^{6}\right.$ cells $\left./ \mathrm{mL}\right)$ & $5.06 \pm 0.02$ & $4.24 \pm 0.04$ & $5.29 \pm 0.39$ & $4.79 \pm 0.05$ \\
\hline Cell density on 10 th day $\left(10^{6}\right.$ cells $\left./ \mathrm{mL}\right)$ & $6.17 \pm 0.08$ & $4.95 \pm 0.01$ & $6.19 \pm 0.14$ & $5.99 \pm 0.05$ \\
\hline Volume-specific TAG on 10th day (mg/L) & $156 \pm 4$ & $135 \pm 9$ & $203 \pm 9$ & $164 \pm 7$ \\
\hline Cell-specific TAG on 10th day (pg/cell) & $25.2 \pm 0.6$ & $27.3 \pm 1.8$ & $32.8 \pm 1.4$ & $27.4 \pm 1.0$ \\
\hline
\end{tabular}

Chaetoceros gracilis cultured in seawater mixed with one or two volumes of sewage water ( 50 and $67 \%$ sewage water), cells used to inoculate sewage water media cultivated first in F/2-enriched seawater (1st subculture) or subcultured once in same sewage water medium (2nd subculture), and $n=3$ 
Table 6 Concentrations of four nutrient salts in sewage water and liquid fertilizer

\begin{tabular}{lllll}
\hline & F/2 (ppm) & Daigo IMK (ppm) & Sewage water (ppm) & Liquid fertilizer (ppm) \\
\hline Phosphate & 3.46 & 3.66 & 4 & 200 \\
Nitrate & 54.7 & 146 & $(7)$ & 0 \\
Nitrite & 0 & 0 & 0.5 & 0 \\
Ammonium & 0 & 0.92 & 18 & 3000 \\
\hline
\end{tabular}

Seawater prepared with sea salts enriched with F/2 medium and with Marine Art SF-1 enriched with Daigo IMK medium and both media subjected to analysis after preparation, values for $\mathrm{F} / 2$ and Daigo IMK calculated from their respective recipes, liquid fertilizer diluted tenfold with pure water and centrifuged at $6500 \times g$ for $10 \mathrm{~min}$ to precipitate suspended materials before analysis, and nitrite presence somewhat disturbed nitrate determinations in sewage water (indicated by parentheses)

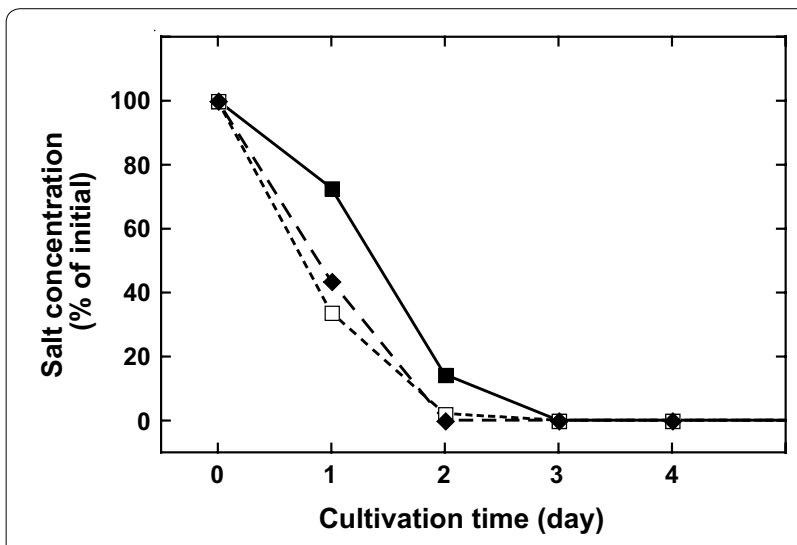

Fig. 2 Changes in concentrations of three nutrient salts during the course of diatom growth. C. gracilis grown in F/2-enriched $1 \% \mathrm{NaCl}$ medium without vitamins, and concentrations of nitrate (closed boxes), silicate (closed diamonds), and phosphate (open boxes) determined at indicated times after cell removal by centrifugation; values normalized at day 0 ; initial concentrations were $50.0,16.4$, and 2.26 ppm for nitrate, silicate, and phosphate, respectively; and some error bars smaller than symbols $(n=3)$

which was lower than $3.46 \mathrm{ppm}$ in $\mathrm{F} / 2$-enriched culture medium (Table 6). Although nitrate concentration was also low in sewage water (Table 6), ammonium should have served as a nitrogen source [75-77]. Ammonium concentrations in 50 and $67 \%$ sewage water culture media were 9.0 and $12 \mathrm{ppm}$, respectively. Because the molecular weight of ammonium is 3.5 times less than nitrate, these concentrations are equivalent to 31 and $42 \mathrm{ppm}$ of nitrate, respectively, which was somewhat lower than that in $F / 2$ medium. As nitrate was consumed at a slower rate than phosphate (Fig. 2), the effect of a somewhat lower nitrogen concentration in sewage water culture media on growth and production might be limited.

Use of liquid fertilizer from cattle feces as a nutrient source Because sewage water was effective for $C$. gracilis cultivation, liquid fertilizer obtained as a waste material after methane fermentation of cattle feces was substituted in place of sewage water (Table 7). The liquid fertilizer contained high concentrations of phosphate and ammonium but no nitrate (Table 6). The $10 \%$ fertilizer (v/v) was centrifuged to remove suspended particles and one-quarter of the supernatant volume added to seawater (final concentration, $2 \%$ by vol). The resulting phosphate and ammonium concentrations were 4.0 and $60 \mathrm{ppm}$, respectively, which were roughly comparable with those in $\mathrm{F} / 2$ medium. Growth in this medium was reduced compared with that in F/2-enriched seawater (Table 7), but TAG accumulation was comparable in the same medium. When cells were subcultured a second time in the same culture medium, growth rate and cell density recovered to those observed in $\mathrm{F} / 2$ medium.

Liquid fertilizer was also tested without removing suspended particles. In medium with $0.5 \%$ liquid fertilizer (by vol), C. gracilis cells grew at a rate comparable to that observed in $\mathrm{F} / 2$-enriched seawater, but TAG production was reduced by about half. When cells were subcultured a second time in the same medium, growth was slightly reduced. However, when cells were cultivated with relatively high fertilizer concentrations ( 1 or $2 \%$ by vol), TAG production was not reduced and growth rate did not decrease after a second subculture in the same medium.

\section{Fatty acid composition under various culture conditions}

The C. gracilis fatty acid (FA) composition, assessed as FA methyl esters (FAME) by gas chromatography-mass spectroscopy (GC-MS, Fig. 3), changed during the time course of growth (Fig. 4). When cells were grown in F/2enriched seawater, palmitic and palmitoleic acids (16:0 and 16:1, respectively) were the dominant fatty acids (24 and $26 \%$ of total FA, TFA, respectively) on the 2nd day of culture. Myristic acid and EPA (14:0 and 20:5 at 11 and $10 \%$ of TFA, respectively) were also remarkable. During the course of growth, 16:0 and 16:1 proportions increased such that their sum reached $\sim 80 \%$ of TFA on the 10th day of culture. Conversely, the proportions of other FAs, including 14:0 and 20:5, decreased. DHA (22:6) was barely detected using the present method of extraction and analysis. Changes in FA composition appeared to be correlated with changes in TAG production in these cells (Fig. 5). 
Table 7 Use of liquid fertilizer as the nutrient source in culture media

\begin{tabular}{|c|c|c|c|c|c|c|c|c|}
\hline & \multicolumn{2}{|c|}{$\begin{array}{l}2 \% \text { supernatant of liquid } \\
\text { fertilizer }\end{array}$} & \multicolumn{2}{|c|}{$0.5 \%$ liquid fertilizer } & \multicolumn{2}{|c|}{$1 \%$ liquid fertilizer } & \multicolumn{2}{|c|}{$2 \%$ liquid fertilizer } \\
\hline & 1st subculture & $\begin{array}{l}\text { 2nd subcul- } \\
\text { ture }\end{array}$ & 1 st subculture & $\begin{array}{l}\text { 2nd subcul- } \\
\text { ture }\end{array}$ & 1 st subculture & $\begin{array}{l}\text { 2nd subcul- } \\
\text { ture }\end{array}$ & 1 st subculture & $\begin{array}{l}\text { 2nd sub- } \\
\text { culture }\end{array}$ \\
\hline $\begin{array}{l}\text { Doubling time } \\
\text { (h) }\end{array}$ & $17.6 \pm 0.5$ & $12.5 \pm 0.3$ & $10.7 \pm 0.1$ & $14.5 \pm 0.1$ & $11.8 \pm 0.1$ & $11.6 \pm 0.3$ & $15.9 \pm 0.7$ & $15.8 \pm 0.5$ \\
\hline $\begin{array}{l}\text { Cell density on } \\
4 \text { th day }\left(10^{6}\right. \\
\text { cells } / \mathrm{mL})\end{array}$ & $3.69 \pm 0.06$ & $4.87 \pm 0.10$ & $4.73 \pm 0.12$ & $4.61 \pm 0.06$ & $5.19 \pm 0.08$ & $6.65 \pm 0.16$ & $6.12 \pm 0.09$ & $6.88 \pm 0.11$ \\
\hline $\begin{array}{l}\text { Cell density on } \\
10 \text { th day }\left(10^{6}\right. \\
\text { cells } / \mathrm{mL})\end{array}$ & $6.06 \pm 0.37$ & $6.69 \pm 0.27$ & $5.38 \pm 0.05$ & $5.59 \pm 0.10$ & $7.71 \pm 0.01$ & $8.75 \pm 0.08$ & $11.6 \pm 0.1$ & $9.88 \pm 0.05$ \\
\hline $\begin{array}{l}\text { TAG on 10th } \\
\text { day (mg/L) }\end{array}$ & $220 \pm 5$ & $181 \pm 3$ & $94.9 \pm 3.4$ & $93.1 \pm 3.8$ & $165 \pm 4$ & $217 \pm 15$ & $213 \pm 2$ & $270 \pm 15$ \\
\hline
\end{tabular}

Liquid fertilizer diluted tenfold ( $10 \%$ by vol) with pure water; resulting $10 \%$ solution, with or without removing suspended materials, diluted further to 5 , 10 , and $20 \%$ $(\mathrm{v} / \mathrm{v})$ with seawater to obtain indicated amounts of liquid fertilizer culture media; cells cultured in resulting medium; cells used to inoculate liquid fertilizer medium cultivated in F/2-enriched seawater (1st subculture) or subcultured once in same liquid fertilizer medium (2nd subculture); and $n=3$

Figure 6 shows FA compositions of cells grown under various culture conditions on the 10th day of culture. When cells were cultivated in F/2-enriched seawater, the two most abundant FAs were 16:0 and 16:1 (47 and 36\% of TFA, respectively), which accounted for over $80 \%$ of TFA. Among the minor FAs, 14:0 and EPA (6.8 and 2.8\% of TFA, respectively) were remarkable. Although the proportion of 16:1 was smaller when liquid fertilizer was used as a nutrient source (Fig. 6, samples 17-20), in general, the sum of 16:0 and 16:1 exceeded 70\% of TFA under all conditions.

\section{Large-scale C. gracilis cultivation in open air}

To examine scalability for industrial purposes, a largescale cultivation of $C$. gracilis was performed in open air without any overhead shelter, using $200 \mathrm{~L}$ of $1 \% \mathrm{NaCl}-$ based medium supplemented with $f$ [78] (Fig. 7). Ambient air and water temperatures fluctuated with the time of day with a mean value of $\sim 30{ }^{\circ} \mathrm{C}$ (Fig. 7b). The highest irradiance at the culture medium surface was about $1700 \mu \mathrm{mol}$ photons $\mathrm{m}^{-2} \mathrm{~s}^{-1}$. Although the irradiance as well as temperature were extremely high compared with laboratory experiments, C. gracilis grew well, showing the highest DT at $7.70 \mathrm{~h}$ and an average DT of $17.8 \mathrm{~h}$ during the first 2 days (Fig. 7a), and cell density after 4 days at $3.14 \times 10^{6}$ cells $/ \mathrm{mL}$. As there was no rain during the 4 experimental days, the culture volume decreased slightly and salinity increased slightly through evaporation (Fig. 7c). The $\mathrm{pH}$ increased in daytime and decreased at night and the volume-specific TAG was $15.8 \mathrm{mg} / \mathrm{L}$ and cell-specific TAG was $5.04 \mathrm{pg} /$ cell after 4 days of culture.

\section{Pigment production under various culture conditions}

Amounts of accumulated pigments, such as fucoxanthin and Chls, were determined after 4 and 8 days (96 and
192 h, respectively) of $C$. gracilis cultivation (Table 8). When cells were grown in $\mathrm{F} / 2$-enriched seawater under continuous light of $50 \mu \mathrm{mol}$ photons $\mathrm{m}^{-2} \mathrm{~s}^{-1}$, Chl $a$ concentration reached $3.38 \mathrm{mg} / \mathrm{L}$ after 4 days of culture. Amounts of Chl $c_{1+2}$ and fucoxanthin, by weight, were $\sim 20$ and $60 \%$, respectively, relative to Chl $a$ at the same time point. Over the next 4 days of culture, the Chl $a$ concentration decreased by $12 \%$, to $2.96 \mathrm{mg} / \mathrm{L}$, while cell density increased 1.6-fold (Fig. 1). After 8 days of culture, the concentrations of fucoxanthin and $\mathrm{Chl} c_{1+2}$ also decreased by $12 \%$ compared with those after $4 \mathrm{~d}$ of culture. When cells were grown in Daigo IMK medium, pigment production was similar to that of cells grown in $\mathrm{F} / 2$ medium after $4 \mathrm{~d}$ of culture. Between 4 and 8 days of culture, the trend was slightly modified, with Chl $a$ and $c_{1+2}$ concentrations decreased to a small extent and fucoxanthin increased by $9 \%$. Chl $c_{3}$ and nonpolar Chl $c$ were not detected here.

Because various culture conditions were effective for growth and TAG accumulation, pigment production was assessed using urea, sewage water, or liquid fertilizer as a nitrogen source (Table 9). When urea was used instead of nitrate, the pigment production trend was similar to that with nitrate. As sewage water collected after a rain was used for this experiment, phosphate and ammonium concentrations in the working culture medium of $67 \%$ sewage water were low, at 1.3 and $6.7 \mathrm{ppm}$, respectively. Under such low nutrient availability, $C$. gracilis grew at reduced growth rate, reaching $2.32 \pm 0.49 \times 10^{6}$ cells $/ \mathrm{mL}$ after 4 days of culture. Because of this reduced growth, the pigments produced were low. During prolonged storage of diluted liquid fertilizer, for $>1$ year, phosphate and nitrate concentrations in $2 \%(\mathrm{v} / \mathrm{v})$ liquid fertilizer culture medium were decreased by about half. With this culture 


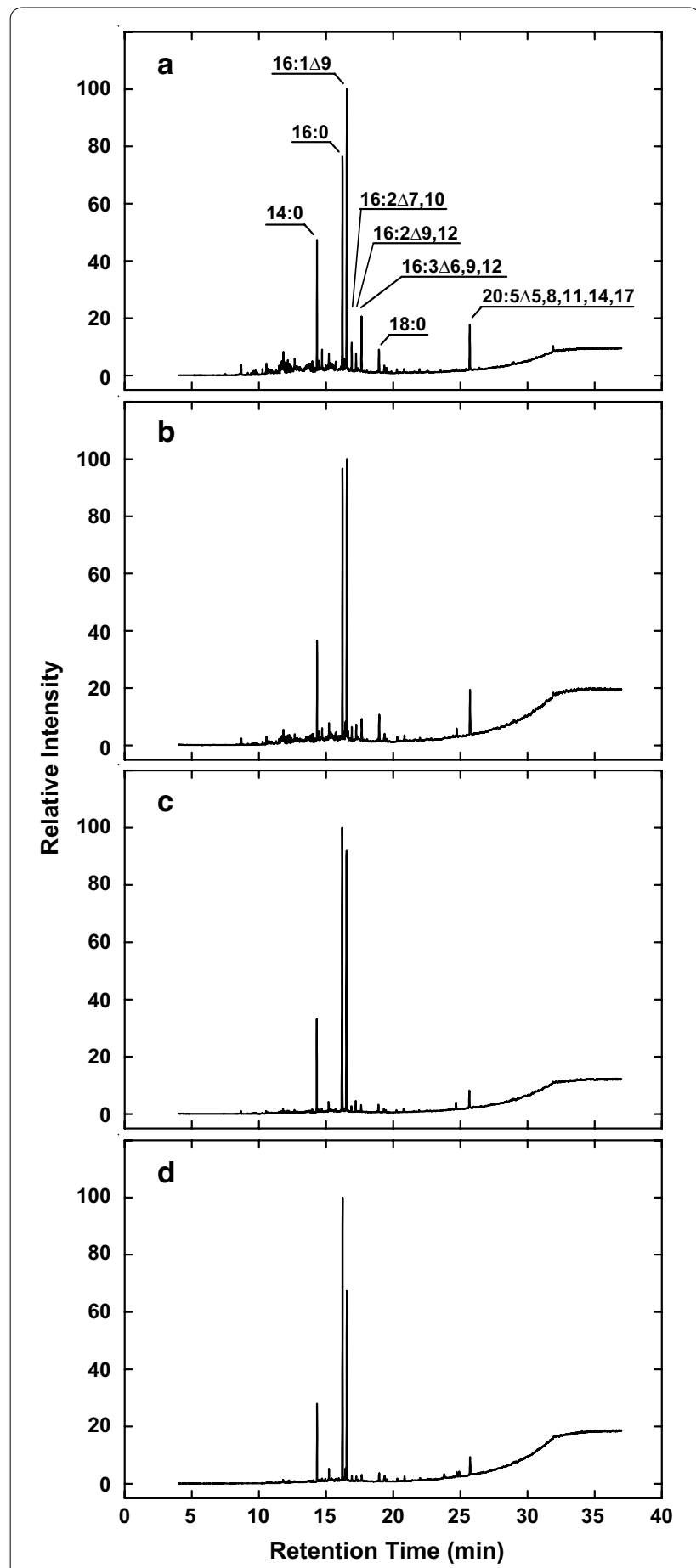

Fig. 3 GC-MS chromatograms of FAME derived from C. gracilis cells grown in $\mathrm{F} / 2$-enriched seawater without vitamins. Cells harvested at day 2, 4, 7, and 10 (a-d, respectively) after culture start; extracted lipids methyl-esterified and subjected to GC-MS; and peak identities indicated on a

medium, C. gracilis grew at a somewhat lower rate compared with $\mathrm{F} / 2$ medium $\left(4.02 \pm 0.30 \times 10^{6}\right.$ cells $/ \mathrm{mL}$ after 4 days of culture) and the amount of accumulated

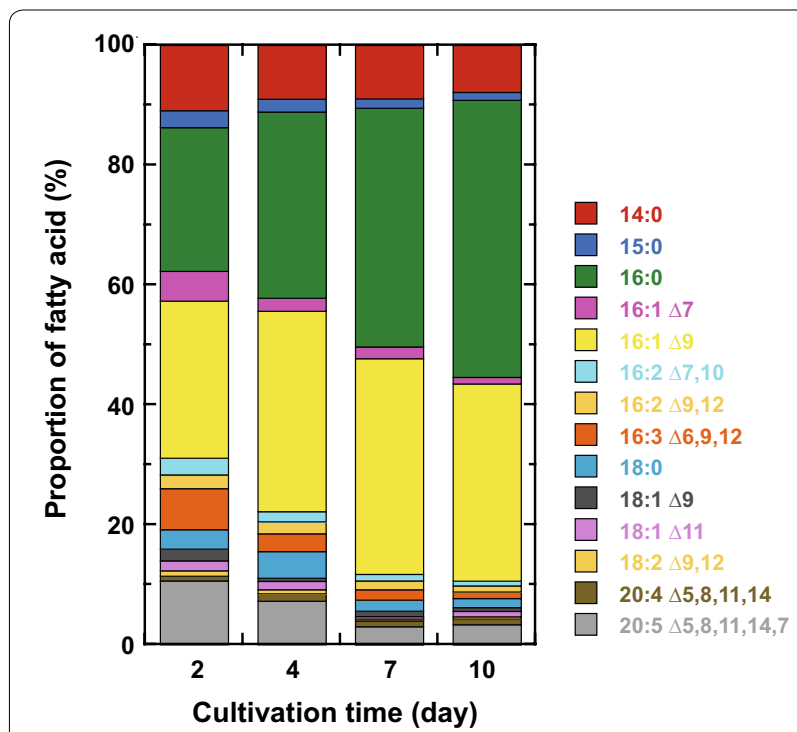

Fig. 4 Changes in FA composition of C. gracilis cells during the course of growth determined by GC-MS in Fig. 5. C. gracilis grown in F/2-enriched seawater without vitamins, cells harvested at indicated times, identities of colored boxes indicated at right, each FA shown as a proportion of TFA, and mean values plotted $(n=3)$

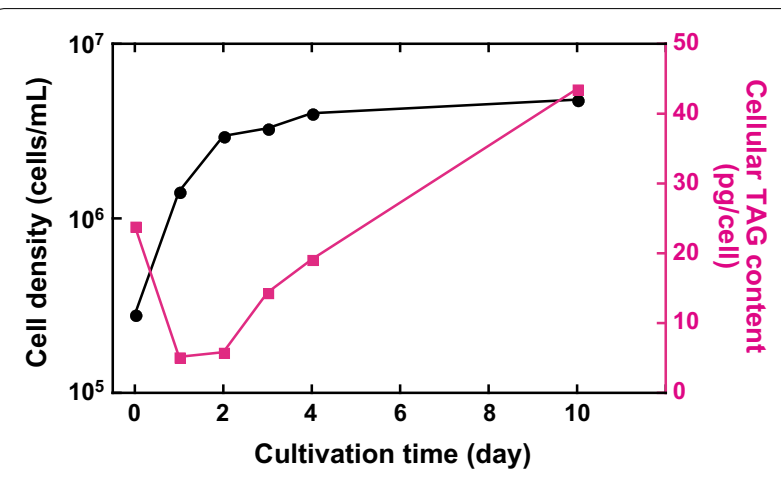

Fig. 5 Changes in cellular TAG content during time course of growth. C. gracilis grown in $\mathrm{F} / 2$-enriched seawater without vitamins, and TAG content and cell density determined at indicated times

pigments reduced to about three-quarters of $F / 2$ medium.

Different from large-scale cultivation performed here in the open air at $\sim 30^{\circ} \mathrm{C}$, all laboratory cultivations in this work were performed at $20{ }^{\circ} \mathrm{C}$ under continuous light. Thus, pigment production was assessed by mimicking open-air conditions, with a photoperiod of $12 / 12 \mathrm{~h}$, light/ dark, with 50 and $100 \mu \mathrm{mol}$ photons $\mathrm{m}^{-2} \mathrm{~s}^{-1}$ at $30{ }^{\circ} \mathrm{C}$ (Table 10). When cells were grown under $50 \mu \mathrm{mol}$ photons $\mathrm{m}^{-2} \mathrm{~s}^{-1}$ for 4 days, the amount of Chl $a(5.09 \mathrm{mg} / \mathrm{L})$ was larger by $\sim 50 \%$ compared with the value for the cells grown for 4 days under continuous light shown in Table 8 $(3.38 \mathrm{mg} / \mathrm{L})$. After a further $6 \mathrm{~d}$ of culture, Chl $a$ amounts 


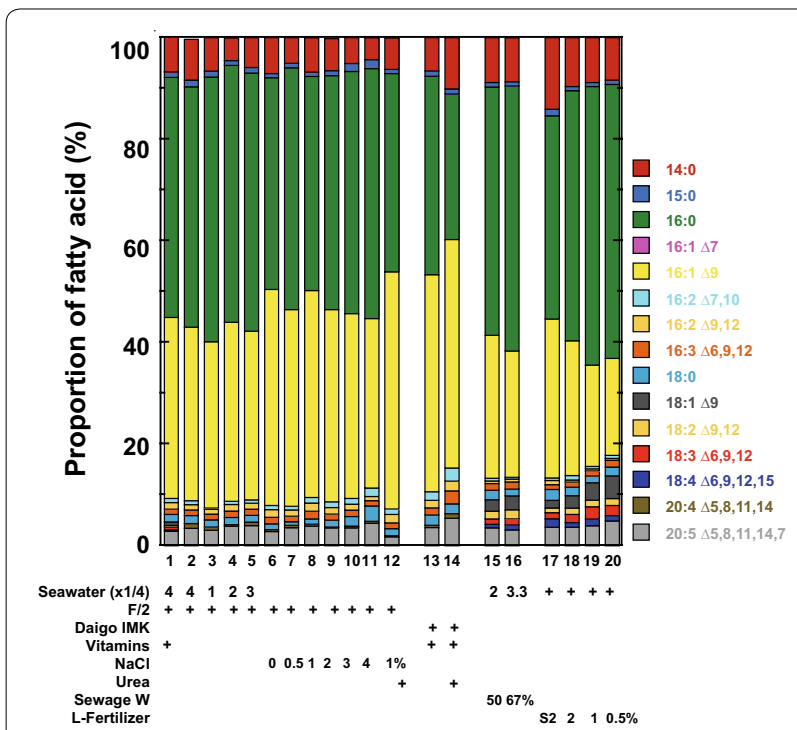

Fig. 6 FA composition of C. gracilis cells grown in various culture media. Cells grown for 10 days in various culture media, including media with low salinity; FA composition assessed by GC-MS, colored box identities on right; each FA as proportion of total FA; and mean values plotted $(n=3)$. The following media used F/2-enriched seawater with vitamins or without vitamins ( 1 and 2 , respectively); F/2-enriched seawater with 1,2 , or $3 \%$ sea salts $(3-5$, respectively); F/2-enriched $\mathrm{NaCl}$ medium with $0,0.5,1,2,3$, or $4 \% \mathrm{NaCl}(6-11$, respectively); F/2-enriched $1 \% \mathrm{NaCl}$ medium with urea (12); Daigo IMK medium (13); Daigo IMK medium with urea (14); seawater diluted with one or two volumes of sewage water ( 15 and 16 , respectively); $2 \%$ liquid fertilizer supernatant in seawater $(17) ; 2,1$, or $0.5 \%$ liquid fertilizer (18-20, respectively) in seawater; and vitamins added to media 1,13 , and 14

increased by $\sim 17 \%(5.98 \mathrm{mg} / \mathrm{L})$, which was different from the trend shown in Tables 8 and 9, in which Chl $a$ amounts decreased. Similar trends in pigment production were observed for other pigments. When cells were grown under higher irradiance for 4 days, the amounts of Chls $a$ and $c_{1+2}$ and fucoxanthin were smaller than in cells grown under lower irradiance but still larger than those in cells grown at lower temperature and continuous light. After an additional 6 days of cultivation, these pigments slightly decreased. Only diadinoxanthin increased under higher irradiance, which might have reflected diadinoxanthin cycle activation to protect cell photosystems from high light.

\section{Discussion}

Diatoms are known as highly productive algae that accumulate high amounts of neutral lipids in their cell bodies [8]. The advantages of diatoms over other microalgae for production applications have been fully discussed elsewhere [11, 79]. Among the many diatom species, the superiority of $C$. gracilis was demonstrated in this study.

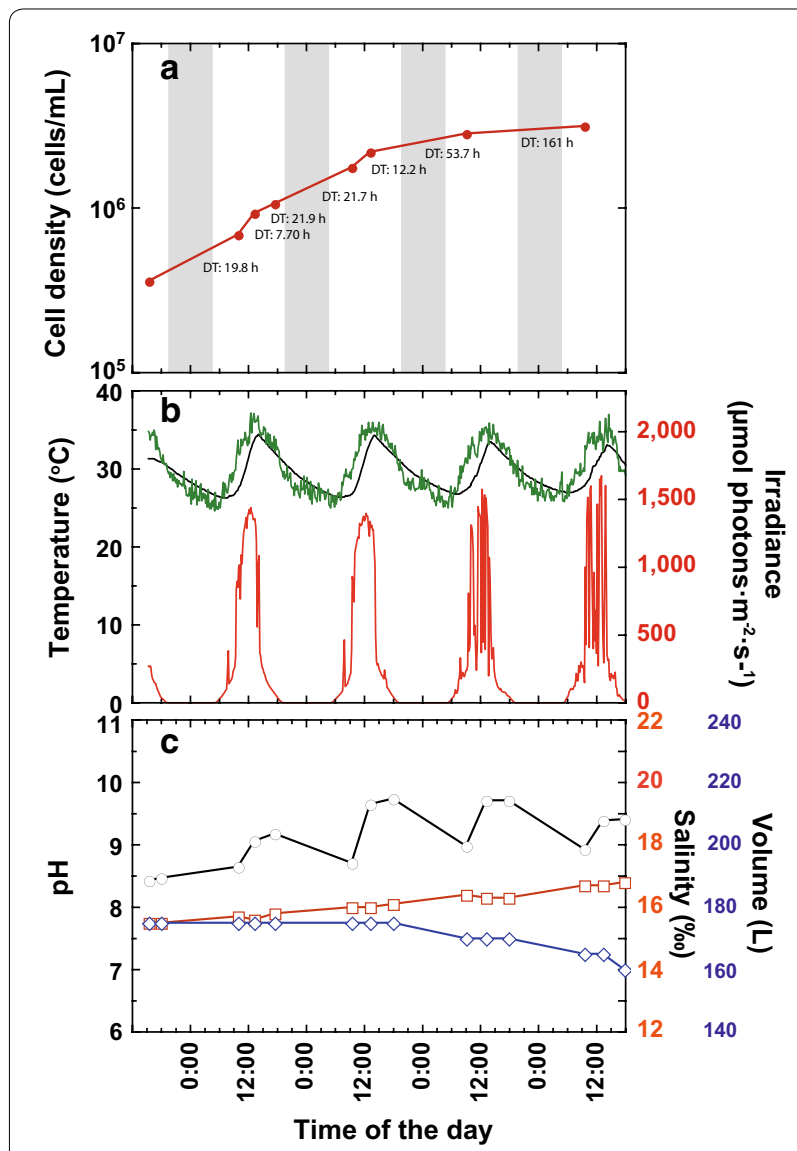

Fig. 7 Open-air large-scale cultivation of C. gracilis. a Changes in cell density. DT designates doubling time between two consecutive time points. b Changes in ambient air, water temperatures, and irradiance (green, black, and red lines, respectively). c Changes in $\mathrm{pH}$, salinity, and volume of culture medium (black, red and blue lines, respectively). Experiment performed from August 3 to 7, 2015

\section{Vitamins are not essential for growth}

Cost is an important consideration for industrial production of valuable metabolites or biofuels using phytoplankton. Vitamins, especially vitamin $B_{12}$, are included in many culture media [80], and many microalgae require vitamins to grow in culture [81]. However, there are also eukaryotic microalgae that do not need vitamins in culture, such as the primitive red alga Cyanidioschyzon merolae [82, 83]. For large-scale phytoplankton culture, the vitamin costs can be considerable. In this work, the effects of vitamins on growth and TAG production in C. gracilis were evaluated by comparison with a model diatom, P. tricornutum (Fig. 1; Table 1). The elimination of vitamins slightly decreased $P$. tricornutum growth and reduced TAG accumulation to one-third of normal using culture medium containing vitamins. It has been reported that vitamin $\mathrm{B}_{12}$ highly accelerates growth of a marine centric diatom, T. pseudonana [81]. Interestingly, 
Table 8 Pigments in Chaetoceros gracilis cells grown for 4 or 8 days in F/2 or Daigo IMK medium

\begin{tabular}{|c|c|c|c|c|}
\hline \multirow[t]{3}{*}{ Pigments } & \multicolumn{4}{|c|}{ Amount of pigments (mg/L) } \\
\hline & \multicolumn{2}{|l|}{$F / 2$} & \multicolumn{2}{|l|}{ Daigo IMK } \\
\hline & 4 days & 8 days & 4 days & 8 days \\
\hline Chlorophyll $a$ & $3.38 \pm 0.39$ & $2.96 \pm 0.07$ & $3.49 \pm 0.06$ & $3.36 \pm 0.07$ \\
\hline Chlorophyll c & $0.734 \pm 0.070$ & $0.646 \pm 0.018$ & $0.761 \pm 0.008$ & $0.741 \pm 0.013$ \\
\hline Fucoxanthin & $1.95 \pm 0.31$ & $1.71 \pm 0.05$ & $2.02 \pm 0.08$ & $2.20 \pm 0.06$ \\
\hline Diadinoxanthin & $0.524 \pm 0.030$ & $0.611 \pm 0.030$ & $0.513 \pm 0.023$ & $0.597 \pm 0.009$ \\
\hline B-Carotene & $0.0962 \pm 0.0113$ & $0.0696 \pm 0.0042$ & $0.0957 \pm 0.0032$ & $0.0720 \pm 0.0055$ \\
\hline
\end{tabular}

Chaetoceros gracilis cells cultivated in F/2-enriched seawater or Daigo IMK culture medium, pigments quantified on days 4 and 8 , and $n$

Table 9 Pigment contents in Chaetoceros gracilis cells grown in various culture media

\begin{tabular}{|c|c|c|c|c|c|c|c|c|}
\hline \multirow{3}{*}{$\begin{array}{l}\text { Pig- } \\
\text { ments }\end{array}$} & \multicolumn{8}{|c|}{ Amount of pigments (mg/L) } \\
\hline & \multicolumn{2}{|l|}{$F / 2$} & \multicolumn{2}{|l|}{ Urea-F/2 } & \multicolumn{2}{|c|}{$67 \%$ sewage water } & \multicolumn{2}{|c|}{$2 \%$ liquid fertilizer } \\
\hline & $96 \mathrm{~h}$ & $240 \mathrm{~h}$ & $96 \mathrm{~h}$ & $240 \mathrm{~h}$ & $96 \mathrm{~h}$ & $240 \mathrm{~h}$ & $96 \mathrm{~h}$ & $240 \mathrm{~h}$ \\
\hline $\begin{array}{l}\text { Chloro- } \\
\text { phyll a }\end{array}$ & $3.77 \pm 0.22$ & $3.22 \pm 0.17$ & $3.45 \pm 0.16$ & $3.00 \pm 0.09$ & $0.778 \pm 0.106$ & $0.710 \pm 0.043$ & $2.85 \pm 0.24$ & $2.33 \pm 0.04$ \\
\hline $\begin{array}{l}\text { Chloro- } \\
\text { phyll c }\end{array}$ & $0.778 \pm 0.050$ & $0.685 \pm 0.040$ & $0.672 \pm 0.028$ & $0.614 \pm 0.014$ & $0.163 \pm 0.018$ & $0.136 \pm 0.010$ & $0.549 \pm 0.036$ & $0.399 \pm 0.006$ \\
\hline $\begin{array}{l}\text { Fucoxan- } \\
\text { thin }\end{array}$ & $2.01 \pm 0.02$ & $1.99 \pm 0.10$ & $1.95 \pm 0.16$ & $1.89 \pm 0.05$ & $0.433 \pm 0.063$ & $0.444 \pm 0.029$ & $1.39 \pm 0.01$ & $1.22 \pm 0.05$ \\
\hline $\begin{array}{l}\text { Diadi- } \\
\text { noxan- } \\
\text { thin }\end{array}$ & $0.535 \pm 0.059$ & $0.564 \pm 0.007$ & $0.493 \pm 0.020$ & $0.529 \pm 0.018$ & $0.140 \pm 0.019$ & $0.193 \pm 0.013$ & $0.361 \pm 0.071$ & $0.375 \pm 0.011$ \\
\hline $\begin{array}{l}\text { B-Caro- } \\
\text { tene }\end{array}$ & $0.115 \pm 0.004$ & $0.0759 \pm 0.0025$ & $0.0681 \pm 0.0310$ & $0.0695 \pm 0.0022$ & $0.0237 \pm 0.0045$ & $0.0255 \pm 0.0010$ & $0.0841 \pm 0.0033$ & $0.0670 \pm 0.0006$ \\
\hline $\begin{array}{l}\text { Phos- } \\
\text { phate } \\
\text { (ppm) }\end{array}$ & 3.46 & & 3.46 & & 1.3 & & 1.73 & \\
\hline $\begin{array}{l}\text { Nitrate } \\
\text { (ppm) }\end{array}$ & 45 & & 0 & & 0 & & 0 & \\
\hline $\begin{array}{l}\text { Ammo- } \\
\text { nium } \\
\text { (ppm) }\end{array}$ & 0 & & 0 & & 6.7 & & 33 & \\
\hline $\begin{array}{l}\text { Cell } \\
\text { density } \\
\text { on 4th } \\
\text { day } \\
\left(10^{6}\right. \\
\text { cells/ } \\
\mathrm{mL})\end{array}$ & $4.25 \pm 0.37$ & & $4.90 \pm 0.31$ & & $2.32 \pm 0.49$ & & $4.02 \pm 0.30$ & \\
\hline $\begin{array}{l}\text { Cell den- } \\
\text { sity on } \\
10 \text { th } \\
\text { day } \\
\left(10^{6}\right. \\
\text { cells/ } \\
\mathrm{mL})\end{array}$ & $6.19 \pm 0.1$ & & $6.43 \pm 0.47$ & & $4.05 \pm 0.41$ & & $4.30 \pm 0.22$ & \\
\hline
\end{tabular}

Chaetoceros gracilis cultured in F/2-enriched seawater inoculated in F/2-enriched seawater, Urea-F/2 medium contained urea not nitrate at same molar concentration, seawater mixed with two volumes of sewage water ( $67 \%$ sewage water medium) or seawater mixed with one-fifth of $10 \%$ ( $/ \mathrm{v}$ ) liquid fertilizer ( $2 \%$ liquid fertilizer medium), pigments quantitated on days 4 and 10 , and $n=3$ 
neither growth rate nor TAG content of $C$. gracilis were affected by vitamin elimination; moreover, both growth and TAG accumulation here were superior in C. gracilis, compared with many other phytoplankton, including other diatoms [9]. Although there remains a possibility of contributions by coexisting microbes, $C$. gracilis was cultivated here without expensive vitamins, which would substantially reduce cultivation costs.

\section{Tolerance to environmental stress}

Diatom growth can be affected by many environmental variables, including temperature, salinity, and nutrient concentrations. C. gracilis grows well under a wide range of temperatures, including $15-35^{\circ} \mathrm{C}$ [84] and also grows well under a wide range of light intensities [34]. In the present study, $C$. gracilis was shown to grow well in media with various sea salt and $\mathrm{NaCl}$ concentrations (Tables 3, 4, respectively). In the field, culture media salinity increased on sunny days with high temperatures and decreased on rainy days. Although $C$. gracilis is a marine diatom, it can acclimate to environments with a wide range of salinity, such that it grew well and accumulated large amounts of TAG under almost all salinity conditions tested in this study $(0-3 \% \mathrm{NaCl})$. C. gracilis' ability to tolerate substantial variations in temperature, light intensity, and salinity would both facilitate industrial-scale cultivation of this diatom and reduce costs associated with controlling culture conditions. The best media found here, fertilizer + seawater, should be further tested against a range of realistic growth temperatures, as all laboratory cultivations were performed at $20^{\circ} \mathrm{C}$. $P$. tricornutum also tolerated various salinities and, given that $P$. tricornutum was isolated from brackish water, low salinity might not be a problem for this diatom. Nonetheless, growth rate and TAG accumulation were much higher in C. gracilis than in P. tricornutum.

\section{Use of sewage water and liquid fertilizer for cultivation}

As C. gracilis was found to grow in media with low salinity, the use of sewage water and liquid fertilizer was investigated for cultivating this diatom. Mixing seawater with sewage water or liquid fertilizer substantially reduced media salinities. In both sewage water and liquid fertilizer, nitrate concentrations were low or negligible and thus ammonium the dominant nitrogen source (Table 7). Nevertheless, by consuming only nutrients contained in sewage water or liquid fertilizer, $C$. gracilis grew well and accumulated large amounts of TAG (Tables 6, 8). In coastal areas, there are usually many sewers that gather wastewater and, thus, establishing cultivation systems near sewage treatment plants could drastically reduce cultivation costs. Furthermore, large amounts of carbon dioxide released from activated sludge in these plants could support active photosynthesis in such cultivation system.

Large quantities of liquid fertilizer are produced as a waste product of methane fermentation of cattle feces, leading to the desire for new uses for this waste product. C. gracilis' growth characteristics were better in media with liquid fertilizer than in media with sewage water (Tables 6, 8). The use of such supplements to cultivate this diatom could reduce cultivation costs and contribute to waste management.

Before expanding these culture media to largescale or long-term cultivation, several points should be addressed. The use of liquid fertilizer supernatant might increase the cost by requiring suspended material removal. The use of liquid fertilizer without removing suspended materials would be more reasonable. Here, the use of $0.5 \%$ liquid fertilizer culture media reduced growth and TAG production at 2nd subculture. Second subculture with sewage water culture media also decreased growth and TAG production (Table 6). In these cases, culture media of precultures should be selected to support reasonable growth in large-scale culture. However, appropriate liquid fertilizer concentrations yielded reasonable growth rates and TAG production even in the 2nd subculture (Table 8), which would contribute in repeated cultivations and/or longterm cultivation. The use of $2 \%$ liquid fertilizer decreased the growth rate but increased TAG production in the 2nd subculture. This might have resulted from reduced light intensity caused by suspended materials in the liquid fertilizer, as the ODs of $2 \%$ liquid fertilizer at 675 and $730 \mathrm{~nm}$ were as high as 1.124 , and 1.008 , respectively.

\section{FA composition}

Microalgae are expected to become a future source of long-chain $n-3$ polyunsaturated FAs, such as EPA and DHA [85], which are valuable materials because they are clinically important [24] and currently obtained mainly from fish oils. In this study of C. gracilis, DHA was scarcely detected, but EPA was the third or fourth most abundant FA (Figs. 4, 5). The EPA proportion in TFA decreased during the time course of growth, which was caused by increased cellular TAG production. However, total cell number also increased, resulting in increased EPA yield.

Although the FA composition changed somewhat during the course of growth, two FAs (16:0 and 16:1) accounted for over $70 \%$ of TFA throughout the growth period (Fig. 4). Furthermore, after 10 days of cultivation, FA composition was not affected by the salinity or nutrient conditions tested here. Therefore, $C$. gracilis was considered to be a stable FA source for biodiesel production. 


\section{Large-scale cultivation of $C$. gracilis in open air}

Chaetoceros gracilis grew well in large-scale cultivation in the open air without $\mathrm{CO}_{2}$ enrichment. The highest and average DT during the first 2 days were 7.7 and $17.8 \mathrm{~h}$, respectively (Fig. 7a). The average growth rate was also comparable with laboratory experiments tested with $C$. gracilis using similar a light/dark cycle at $28{ }^{\circ} \mathrm{C}$ (DT of $\sim 12 \mathrm{~h},[86])$. It was also comparable to the growth rate of C. muelleri tested at $30{ }^{\circ} \mathrm{C}$ under continuous light (DT of $\sim 12 \mathrm{~h}$, [84]). In addition, this was comparable with the highest growth rate obtained with a similar light/dark cycle in small-scale laboratory culture at $20{ }^{\circ} \mathrm{C}$ (DT of $15 \mathrm{~h}$ for Cylindrotheca fusiformis and Pseudo-nitzschia pseudodelicatissima [9]). Although pigment analysis using cells cultivated in open-air was not performed, high production of valuable pigments, such as fucoxanthin, could be achieved with C. gracilis, as this species showed high pigment production under an environment simulating open-air cultivation (Table 10). Because cells grew well under open-air light conditions (Fig. 7), light intensity at the water surface, much higher than that used in Table 10, should not have affected pigment production negatively.

\section{Pigments}

$\mathrm{Chl} a$ is one of the dominant diatomaceous photosynthetic pigments and is currently purified from microalgae or spinach. Industrial diatom cultivation in the near future could yield large amounts of Chl $a$ as a cellular debris residue from other processes. Chls have several potential uses, such as serving as sensitizers for light-capturing materials in solar panels.

$\mathrm{Chl} c$, having no phytol group, is a polar molecule compared to other Chls, a feature that increases the variety of its potential uses. Allophycocyanin, a water-soluble blue pigment and photosynthetic chromophore in cyanobacteria and red algae, is used as a fluorescent label for immunodetection and as a food colorant [87]. Chl $c$, a brown-yellow pigment, can also be used as a food colorant [88]. Furthermore, $\mathrm{Chl} c$ is a porphyrin, similar to the heme in hemoglobin, whereas other types of $\mathrm{Chl}$ are chlorins. This structural similarity with heme could allow Chl $c$ to be used for pharmaceutical purposes.

Fucoxanthin, one of the xanthophylls expected to be commercially produced [89], could be beneficial to human health. There are many reports of fucoxanthin's inhibitory effects on cancer cells [28-33], and its antioxidant effects are also well known [37]. Fucoxanthin is usually purified from edible brown algae, such as Laminaria spp. [37], which are abundant and useful as human food. Diatoms can be ideal biofactories for industrial fucoxanthin production because they use solar energy to drive biosynthesis. It is noteworthy that both $C$. gracilis' fucoxanthin content (Table 8) and growth rates were high in the present study. Furthermore, nutrient costs could be kept low by using wastewater as a nutrient source (Tables 5, 7).

For fucoxanthin purification from brown algae, $1 \mathrm{~g}$ of wet algal body, for example, is soaked in $30 \mathrm{~mL}$ of methanol for 2 days, producing a fucoxanthin yield of $0.24-0.43 \mathrm{mg} / \mathrm{g}$, as has been reported by Mori et al. [37]. Comparable fucoxanthin amounts $(\sim 0.3 \mathrm{mg}$ fucoxanthin/g) from $1 \mathrm{~g}$ of wet brown algal body could be purified here from about $150 \mathrm{~mL}$ of culture at stationary phase (Table 8 ). In accordance with the usual wet weight of this diatom, at $0.5-0.6 \%(\mathrm{w} / \mathrm{v})$ of culture medium, after 4-10 days of cultivation using F/2 medium in the present experiments, the wet weight here should be $\sim 0.9 \mathrm{~g}$ for $\sim 150 \mathrm{~mL}$ of culture. If methanol is used in the same proportion to diatom wet weight as for brown algae, comparable methanol amounts are needed. However, as diatoms are unicellular organisms, the required solvent should be less than that calculated above and the extraction time for pigments extremely short, at $<1 \mathrm{~h}$. Therefore, fucoxanthin could be purified, with little oxidation damage, via a short isolation period

Table 10 Amounts of pigments in Chaetoceros gracilis cells grown under $12 \mathrm{~h}$ light/12 h dark at $30^{\circ} \mathrm{C}$

\begin{tabular}{|c|c|c|c|c|}
\hline \multirow[t]{3}{*}{ Pigments } & \multicolumn{4}{|c|}{ Amount of pigments (mg/L) } \\
\hline & \multicolumn{2}{|c|}{$50 \mu \mathrm{mol}$ photons $\mathrm{m}^{-2} \mathrm{~s}^{-1}$} & \multicolumn{2}{|c|}{$100 \mu \mathrm{mol}$ photons $\mathrm{m}^{-2} \mathrm{~s}^{-1}$} \\
\hline & $96 \mathrm{~h}$ & $240 \mathrm{~h}$ & $96 \mathrm{~h}$ & $240 \mathrm{~h}$ \\
\hline Chlorophyll a & $5.09 \pm 0.15$ & $5.98 \pm 0.65$ & $4.55 \pm 0.10$ & $4.34 \pm 0.09$ \\
\hline Chlorophyll C & $0.965 \pm 0.031$ & $0.924 \pm 0.028$ & $0.844 \pm 0.023$ & $0.771 \pm 0.020$ \\
\hline Fucoxanthin & $2.67 \pm 0.11$ & $2.92 \pm 0.09$ & $2.52 \pm 0.02$ & $2.45 \pm 0.08$ \\
\hline Diadinoxanthin & $0.575 \pm 0.034$ & $1.18 \pm 0.05$ & $0.853 \pm 0.034$ & $0.962 \pm 0.013$ \\
\hline ß-Carotene & $0.186 \pm 0.006$ & $0.203 \pm 0.011$ & $0.180 \pm 0.004$ & $0.164 \pm 0.003$ \\
\hline Cell density $\left(10^{6}\right.$ cells/mL) & $4.54 \pm 0.13$ & $6.45 \pm 0.27$ & $5.39 \pm 0.07$ & $6.92 \pm 0.16$ \\
\hline
\end{tabular}

Cells cultivated in $\mathrm{F} / 2$-enriched seawater under a photoperiod of $12 \mathrm{~h}$ light/ $12 \mathrm{~h}$ dark with 50 or $100 \mu$ mol photons $\mathrm{m}^{-2} \mathrm{~s}^{-1}$ at $30^{\circ} \mathrm{C}$, pigments quantitated on days 4 and 10 , and $n=3$ 
and with lower costs compared with current fucoxanthin sources.

The costs for pigment production also depend on cultivation methods. Here, urea was an effective nitrogen source for growth (Table 5), which reduced the cultivation cost by taking the place of nitrate. With this replacement, pigment production comparable to $\mathrm{F} / 2$-enriched culture medium was achieved (Table 9). Sewage water and liquid fertilizer were effective low-cost additives as main nitrogen and phosphate sources to support growth and TAG accumulation (Tables 5, 7). Because sewage water used to cultivate cells for pigment analysis was collected just after a rain, phosphate and nitrogen source concentrations were low. Concentrations of such nutrients in diluted liquid fertilizer were also decreased after long-term storage. These effects on pigment production when using sewage water and liquid fertilizer were not considered large after examination of the results shown in Tables 5 and 7. However, limited levels of pigment production were supported even under such poor conditions.

\section{Conclusions}

In this report, a marine centric diatom, C. gracilis, was shown to possess high tolerances to environmental stressors, such as changes in salinity, and to grow well under a variety of conditions, yielding large amounts of TAG and EPA. Cell growth and TAG production by $C$. gracilis were superior to those of $P$. tricornutum, which has been used in many studies into its potential industrial applications, including oil production $[64,90]$. Furthermore, $C$. gracilis growth was faster than many other diatoms and green algae and, although direct comparisons are difficult, lipid production was also higher in $C$. gracilis than in these organisms [9]. While growth and TAG production of $C$. gracilis were satisfactory in most culture media tested, F/2-enriched with $1 \% \mathrm{NaCl}$ solution was the most effective for both growth and TAG accumulation. Under this condition, C. gracilis showed clear advantage over other microalgae including oleaginous diatoms on the growth rate and TAG productivity (Table 11). It is also noteworthy that only two fatty acids are dominated FAME compounds; palmitic (16:0) and palmitoleic (16:1) acids in C. gracilis. Twenty percent liquid fertilizer was also effective, supporting high TAG production at a reasonable growth rate.

It was also shown that $C$. gracilis produced high amounts of TAG without the need for nitrogen or silica deprivation, which is frequently imposed on many other microalgae to induce lipid production [17, 23]. Processes for producing nitrogen or silica deprivation require cell transfer into nutrient-free medium, which incurs added labor, high costs, and complicates scalability. The ability of this microalga to accumulate TAG without nutrient deprivation is important for low-cost scalability.

A stable and efficient genetic transformation technique for C. gracilis was developed in a previous study by this group [74]. Using this highly productive diatom, a platform to produce valuable metabolites could be constructed by introducing exogenous genes. Because C. gracilis produces large amounts of fucoxanthin and lipids, derivatives of these molecules could also be produced in large quantities. In addition, C. gracilis grows well and produces abundant fucoxanthin and lipids using sewage water or liquid fertilizer derived from cattle feces without carbon dioxide supplementation. Thus, production costs could be quite low. C. gracilis shows great potential as a biofactory.

\section{Methods}

\section{Diatom strains and growth conditions}

A centric marine diatom, Chaetoceros gracilis Schütt (UTEX LB 2658), and a pennate marine diatom, Phaeodactylum tricornutum Böhlin (UTEX 642), were used in this study. The cells were grown photoautotrophically in artificial seawater (sea salts; Sigma-Aldrich, Inc., St. Louis, MO, USA, or Marine Art SF-1; Tomita Pharmaceutical Co., Ltd., Naruto, Japan) supplemented with $\mathrm{F} / 2$ (half-strength medium $f$ [78]) or Daigo IMK medium (Nihon Pharmaceutical Industry Co., Ltd., Tokyo, Japan) at $20{ }^{\circ} \mathrm{C}$ and with ambient air bubbled through the media [50]. The concentrations of copper and molybdenum were 10 times that of original $\mathrm{F} / 2$ without any positive/negative effects on growth. The initial culture volume was $70 \mathrm{~mL}$ in glass tubes $(30 \mathrm{~mm}$ dia $\times 200 \mathrm{~mm}$ long; $\sim 90 \mathrm{~mL}$ vol). Because sea salts and Marine Art SF-1 did not contain silicate, $15 \mathrm{mg} / \mathrm{L}$ $\mathrm{NaSiO}_{3} \cdot 9 \mathrm{H}_{2} \mathrm{O}$ was added to all culture media. When necessary, vitamins $\left(0.5 \mu \mathrm{g} / \mathrm{L} \mathrm{B}_{12}, 0.5 \mu \mathrm{g} / \mathrm{L}\right.$ biotin, and $100 \mu \mathrm{g} / \mathrm{L}$ thiamine- $\mathrm{HCl}$ ) were added to the medium. Where indicated, a $\mathrm{NaCl}$-based solution, containing variable concentrations of $\mathrm{NaCl}, 1.33 \% \mathrm{MgSO}_{4} \cdot 7 \mathrm{H}_{2} \mathrm{O}$, $0.147 \% \mathrm{CaCl}_{2} \cdot 2 \mathrm{H}_{2} \mathrm{O}, 0.080 \% \mathrm{KCl}$, and $0.025 \% \mathrm{NaHCO}_{3}$ $(\mathrm{w} / \mathrm{v})$ were used instead of artificial seawater. Urea as a nitrogen source was assessed by substituting urea for nitrate in media at the same molar concentration. All chemicals were of a high purity.

Sewage water and liquid fertilizer were used here as additives to culture media. Sewage water was obtained from Harima Kogen Higashi Waterworks, located near the Harima Campus for Science of the University of Hyogo, Hyogo Prefecture, Japan $\left(35^{\circ} 55^{\prime} \mathrm{N}, 134^{\circ} 26^{\prime} \mathrm{E}\right)$. Liquid fertilizer, from cattle feces fermentation, was supplied by Marubeni Corp., Kyushu Branch (Fukuoka, Japan). To prepare working culture media by diluting seawater, trace metals and silicate were added to the same 


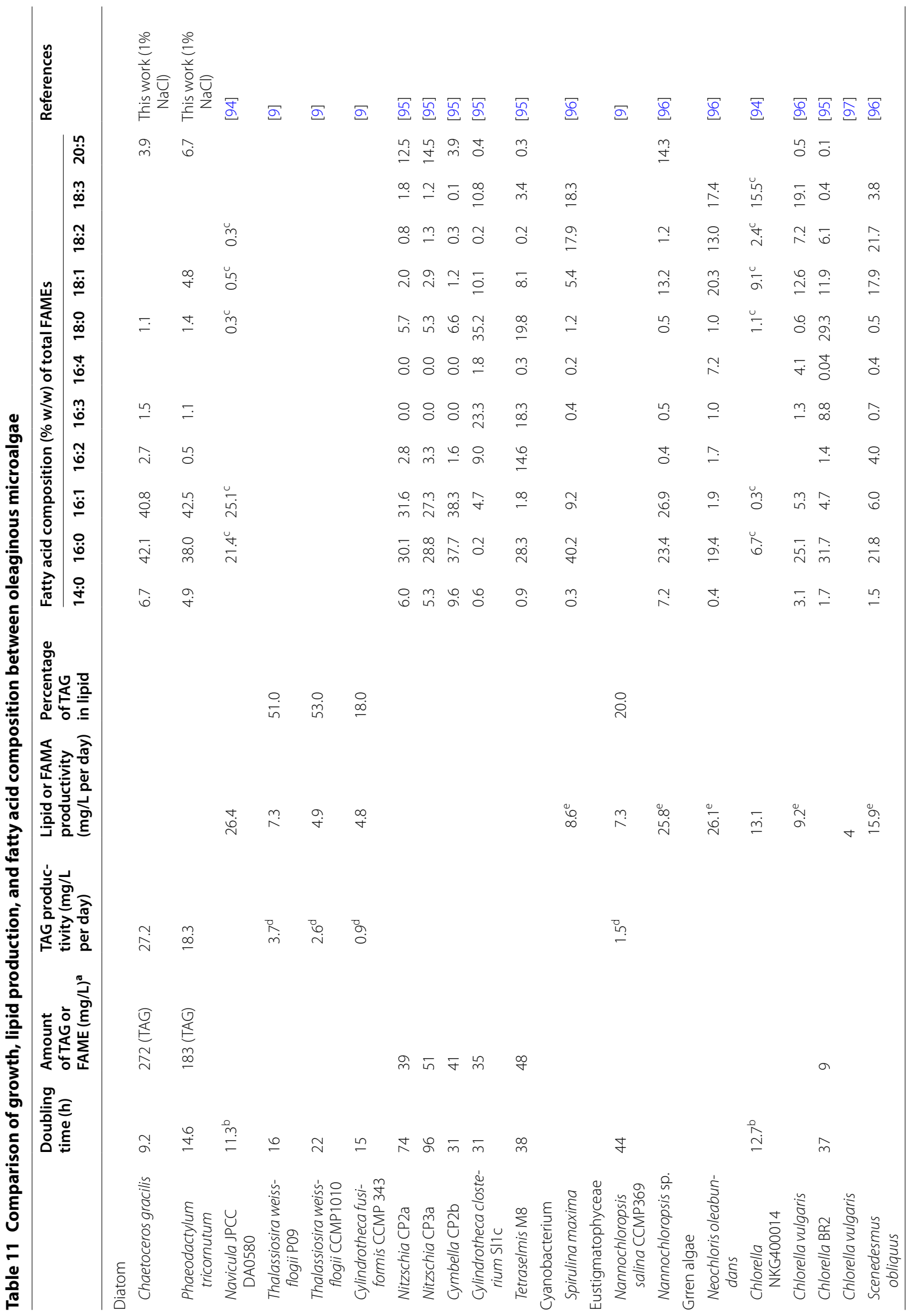




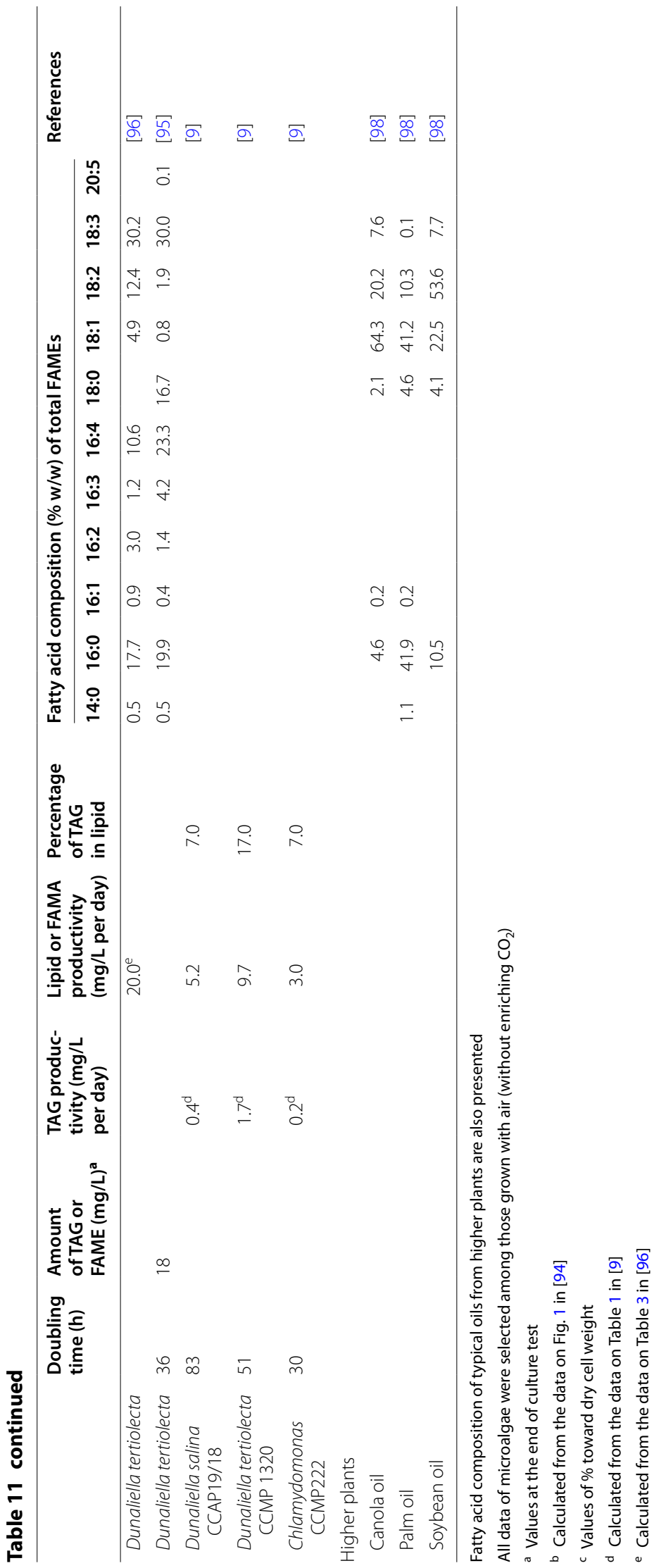




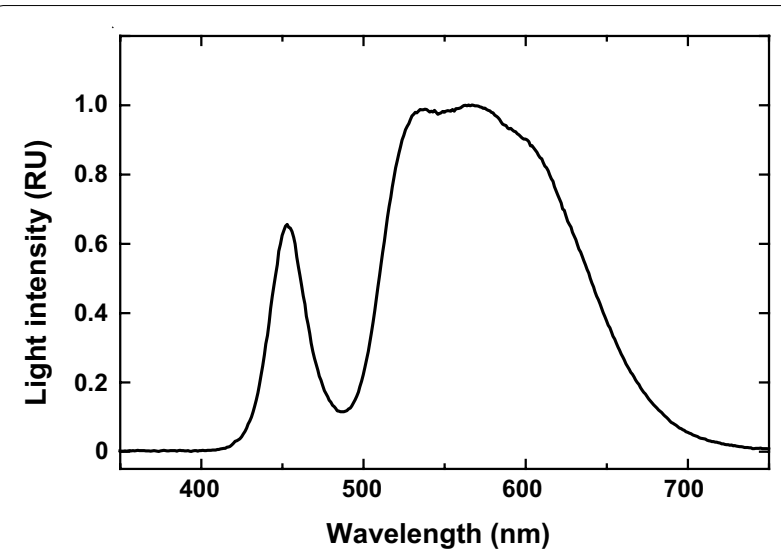

Fig. 8 Spectral properties of LED light source used for C. gracilis culture. Wavelength-dependent intensity determined using a spectrometer BRC115 (B\&W Tek, Inc., Newark, DE, USA) and normalized at peak wavelength

concentrations as in F/2 medium. All experiments were performed using cells subcultured at least twice in the same medium, unless otherwise indicated.

Continuous light was supplied by a warm, white, LED light source (VBL-SD150-LL; Valore Corp., Kyoto, Japan), whose spectral properties are shown in Fig. 8. The photon irradiance, measured using a quantum photometer (LI-COR Biosciences, Inc., Lincoln, NE, USA), was $50 \mu \mathrm{mol}$ photons $\mathrm{m}^{-2} \mathrm{~s}^{-1}$. Cell density was determined by cell counting with a hemocytometer.

Open-air culture of C. gracilis was performed at the Harima Campus for Science of the University of Hyogo using a plastic tank (width/depth/height, $1045 \times 785 \times 802 \mathrm{~mm}$, respectively $)$ with $\sim 200 \mathrm{~L}(\sim 25 \mathrm{~cm}$ depth) of $1 \% \mathrm{NaCl}$-based culture medium supplemented with $f$ [78]. Irradiance, illumination intensity, and temperatures were measured using a quantum photometer ML020P, a pyranometer MS-602 (Eko Instruments Co., Ltd., Tokyo, Japan), and type $\mathrm{T}$ thermocouple probes, respectively, and data stored in a GL220 data logger (Graphtec Corp., Yokohama, Japan).

\section{Pigment analysis}

Photosynthetic pigments were quantified using reversedphase high-performance liquid chromatography by a LC-10AD with a SCL-10A system controller (Shimadzu Co., Ltd., Kyoto, Japan) and equipped with a Prodegy 5 column (ODS, $150 \times 4.60 \mathrm{~mm}$ ) supplied by Phenomenex Inc., (Torrance, CA, USA), as described previously [50], after extraction in N,N-dimethylformamide [35, 91]. Standard pigments were purchased from VKI Water Quality Institute (Hoersholm, Denmark). Chl $a$ concentrations were determined as described by Porra et al. [92], using methanol as the solvent.

\section{Nutrient analyses}

Concentrations of nutrients, including nitrate, nitrite, ammonium, phosphate, and silica, were determined using PACKTEST kits (Kyoritsu Chemical-Check Lab Corp., Tokyo, Japan), per manufacturer's instructions. Obtained concentrations were $20 \%(20.3 \pm 1.0 \%$ for nitrate and $20.8 \pm 3.0 \%$ for phosphate, $n=2$ ) lower than their expected values calculated from the $F / 2$ recipe.

\section{TAG and FA analyses}

Diatom cells were harvested from $2 \mathrm{~mL}$ of cell suspension by centrifugation at $1000 \times g$ and $4{ }^{\circ} \mathrm{C}$. Lipids were extracted using the method of Bligh and Dyer [93] with slight modifications. In brief, the precipitated diatom cells were suspended in $1.2 \mathrm{~mL}$ of pure water and then $1.5 \mathrm{~mL}$ of chloroform and $3 \mathrm{~mL}$ of methanol were added. After cell disruption by ultrasonication for $5 \mathrm{~min}$ using a B2200 ultrasonic cleaner (Branson Ultrasonics Corp., Danbury, CT, USA), $1.5 \mathrm{~mL}$ of chloroform and $1.5 \mathrm{~mL}$ of pure water were added. After centrifugation at $400 \times g$ at $4{ }^{\circ} \mathrm{C}$, the lipid-containing lower solvent phase was recovered. Additional lipids were recovered by the same procedure after adding $1.2 \mathrm{~mL}$ of chloroform to the upper aqueous phase from the previous extraction. The combined solvent phases were dried using a centrifugal concentrator (5305; Eppendorf AG, Hamburg, Germany) and then dissolved in $200 \mu \mathrm{L}$ of 2-propanol. TAG contents were determined using a TAG quantification kit (Triglyceride E-Test Wako; Wako Pure Chemical Industries, Ltd., Osaka, Japan), based on a method using glycerol-3-phosphate oxidase and 3,5-dimethoxy- $N$-ethyl- $N$-( $2^{\prime}$-hydroxy$3^{\prime}$-sulfopropyl)-aniline sodium salt, per manufacturer's instructions. TAG concentrations were expressed as triolein equivalents.

After methyl esterification, the acyl composition in TAG was determined by GC-MS (GCMS-QP2010 Ultra, Shimadzu Corp., Kyoto, Japan). FA methyl esterification was performed with a FA methylation kit and the resulting FAMEs purified using a FAME purification kit (Nacalai Tesque, Inc., Kyoto, Japan). FAMEs were analyzed using an Agilent DB-23 column (30 m length, $0.25 \mathrm{~mm}$ diameter, and $0.25 \mathrm{~mm}$ film thickness; Agilent Technologies, Inc., Santa Clara, CA, USA). The inlet and detector temperatures were set to $250{ }^{\circ} \mathrm{C}$, and $0.5-$ $1.0 \mu \mathrm{L}$ of each sample was analyzed using splitless injection and a constant flow rate of $1.22 \mathrm{~mL} / \mathrm{min}$. The oven temperature program was set to start at $50{ }^{\circ} \mathrm{C}$ for $2 \mathrm{~min}$, increased to $180{ }^{\circ} \mathrm{C}$ at a $10{ }^{\circ} \mathrm{C} / \mathrm{min}$, held at $180{ }^{\circ} \mathrm{C}$ for $5 \mathrm{~min}$, increased to $240{ }^{\circ} \mathrm{C}$ at $5{ }^{\circ} \mathrm{C} / \mathrm{min}$, and finally held at $240{ }^{\circ} \mathrm{C}$ for $5 \mathrm{~min}$. FAMEs separated by GC were detected and analyzed on a mass spectrometer operating in scan mode. Mass spectra were recorded every $0.03 \mathrm{~s}$ over an $\mathrm{m} / \mathrm{z}$ range of $60-600$. FAMEs were identified using the 
NIST/EPA/NIH Mass Spectral Database, 2011 edition, and GC-MS solution software (Shimadzu Corp.).

\author{
Abbreviations \\ Chl: chlorophyll; DHA: docosahexaenoic acid; DT: doubling time; EPA: eicosa- \\ pentaenoic acid; FA: fatty acid; FAME: fatty acid methyl esters; GC-MS: gas \\ chromatography-mass spectroscopy; TAG: triacylglycerol; TFA: total fatty acids.
}

\section{Authors' contributions}

YK and $\mathrm{Kl}$ conceived and designed the experiments; $\mathrm{HT}, \mathrm{NI}-\mathrm{K}, \mathrm{YN}$, and $\mathrm{AM}$ performed the experiments and analyzed the data; $Y K$ and KI wrote the paper. All authors read and approved the final manuscript.

\begin{abstract}
Author details
1 Graduate School of Life Science, University of Hyogo, 3-2-1 Koto, Kamigori, Ako-gun, Hyogo 678-1297, Japan. ${ }^{2}$ Yanmar Environmental Sustainability Support Association, Umeda Gate-Tower, 1-9 Tsuruno, Kita-ku, Osaka 530-8311, Japan. ${ }^{3}$ Present Address: College of Agriculture, Tamagawa University, 6-1-1 Tamagawagakuen, Machida, Tokyo 194-8610, Japan. ${ }^{4}$ Graduate School of Biostudies, Kyoto University, Kyoto 606-8502, Japan.
\end{abstract}

\section{Acknowledgements}

We thank Harima Kogen Higashi Waterworks for providing sewage water and vice-president Masaaki Satoh of Marubeni Corporation, Kyushu Branch, for providing liquid fertilizer originating from cattle feces. We are also grateful to Ms. Tomoko Ishihara, Mari Sasase, Yuiko Satoh, and Rui Yamasaki for their technical assistance and Valore Corporation for measuring spectral properties of the LED light source.

\section{Competing interests}

The authors declare that they have no competing interests.

\section{Availability of data and material}

All datasets on which the conclusions of the manuscript rely are presented in the main paper.

\section{Funding}

This work was supported by the Japan Science and Technology AgencyAdvanced Low Carbon Technology Research and Development Program (2100053) and the New Energy and Industrial Technology Development Organization-New Energy Venture Business Technology Innovation Program (14102439-0).

Received: 12 August 2016 Accepted: 17 October 2016

Published online: 03 November 2016

\section{References}

1. Sims PA, Mann DG, Medlin LK. Evolution of the diatoms: insights from fossil, biological and molecular data. Phycologia. 2006;4:361-402.

2. Kooistra WHCF, Gersonde R, Medina M, Mann DG. The origin and evolution of the diatoms: their adaptation to a planktonic existence. In: Falkowski P, Knoll AH, editors. Evolution of Primary producers in the sea. Burlington: Elsevier Academic Press; 2007. p. 207-49.

3. Damste JS, Muyzer G, Abbas B, Rampen SW, Masse G, Allard WG, Belt ST, Robert JM, Rowland SJ, Moldowan JM, Barbanti SM, Fago FJ, Denisevich P, Dahl J, Trindade LA, Schouten S. The rise of the rhizosolenid diatoms. Science. 2004;304(5670):584-7.

4. Aoyagi K, Omokawa M. Neogene diatoms as the important source of petroleum in Japan. J Petrol Sci Eng. 1992;7:247-62.

5. Grantham PJ, Wakefield LL. Variations in the sterane carbon number distributions of marine source rock derived crude oils through geological time. Org Geochem. 1988;12:61-73.

6. Field CB, Behrenfeld MJ, Randerson JT, Falkowski P. Primary production of the biosphere: integrating terrestrial and oceanic components. Science. 1998;281(5374):237-40.
7. Nelson DM, Treguer P, Brzezinski MA, Leynaert A, Queguiner B. Production and dissolution of biogenic silica in the ocean: revised global estimates, comparison with regional data and relationship to biogenic sedimentation. Glob Biogeochem Cycles. 1995;9:359-72.

8. Chisti Y. Biodiesel from microalgae. Biotechnol Adv. 2007;25(3):294-306.

9. d'Ilppolito G, Sardo A, Paris D, Vella FM, Adelfi MG, Botte P, Gallo C, Fontana A. Potential of lipid metabolism in marine diatoms for biofuel production. Biotechnol Biofuels. 2015;8:28.

10. Sicko-Goad LM, Schelske CL, Stoermer EF. Estimation of intracellular carbon and silica content of diatoms from natural assemblages using morphometric techniques. Limnol Oceanogr. 1984;29(6):1170-8.

11. Ramachandra TV, Mahapatra DM, Karthick B, Gordon R. Milking diatoms for sustainable energy: biochemical engineering versus gasoline-secreting diatom solar panels. Ind Eng Chem Res. 2009;48(19):8769-88.

12. Appeltans W, Ahyong ST, Anderson G, Angel MV, Artois T, Bailly N, Bamber R, Barber A, Bartsch I, Berta A, Blazewicz-Paszkowycz M, Bock P, Boxshall G, Boyko CB, Brandao SN, Bray RA, Bruce NL, Cairns SD, Chan TY, Cheng L, Collins AG, Cribb T, Curini-Galletti M, Dahdouh-Guebas F, Davie PJ, Dawson MN, De Clerck O, Decock W, De Grave S, de Voogd NJ, Domning DP, Emig CC, Erseus C, Eschmeyer W, Fauchald K, Fautin DG, Feist SW, Fransen CH, Furuya H, Garcia-Alvarez O, Gerken S, Gibson D, Gittenberger A, Gofas S, Gomez-Daglio L, Gordon DP, Guiry MD, Hernandez F, Hoeksema BW, Hopcroft RR, Jaume D, Kirk P, Koedam N, Koenemann S, Kolb JB, Kristensen RM, Kroh A, Lambert G, Lazarus DB, Lemaitre R, Longshaw M, Lowry J, Macpherson E, Madin LP, Mah C, Mapstone G, McLaughlin PA, Mees J, Meland K, Messing CG, Mills CE, Molodtsova TN, Mooi R, Neuhaus B, Ng PK, Nielsen C, Norenburg J, Opresko DM, Osawa M, Paulay G, Perrin W, Pilger JF, Poore GC, Pugh P, Read GB, Reimer JD, Rius M, Rocha RM, Saiz-Salinas JI, Scarabino V, Schierwater B, Schmidt-Rhaesa A, Schnabel KE, Schotte M, Schuchert P, Schwabe E, Segers H, Self-Sullivan C, Shenkar N, Siegel V, Sterrer W, Stohr S, Swalla B, Tasker ML, Thuesen EV, Timm T, Todaro MA, Turon X, Tyler S, Uetz P, van der Land J, Vanhoorne B, van Ofwegen LP, van Soest RW, Vanaverbeke J, Walker-Smith G, Walter TC, Warren A, Williams GC, Wilson SP, Costello MJ. The magnitude of global marine species diversity. Curr Biol. 2012;22(23):2189-202.

13. Mann DG, Droop SJM. Biodiversity, biogeography and conservation of diatoms. Hydrobiologia. 1996;336:19-32.

14. Guiry MD. How many species of algae are there? J Phycol. 2012;48:1057-63.

15. Tanaka T, Maeda Y, Veluchamy A, Tanaka M, Abida H, Marechal E, Bowler C, Muto M, Sunaga Y, Tanaka M, Yoshino T, Taniguchi T, Fukuda Y, Nemoto M, Matsumoto M, Wong PS, Aburatani S, Fujibuchi W. Oil accumulation by the oleaginous diatom Fistulifera solaris as revealed by the genome and transcriptome. Plant Cell. 2015;27(1):162-76.

16. McGinnis KM, Dempster TA, Sommerfeld MR. Characterization of the growth and lipid content of the diatom Chaetoceros muelleri. J Appl Phycol. 1997;9:19-24.

17. Adams C, Bugbee B. Enhancing lipid production of the marine diatom Chaetoceros gracilis: synergistic interactions of sodium chloride and silicon. J Appl Phycol. 2014;26:1351-7.

18. Hu Q, Sommerfeld M, Jarvis E, Ghirardi M, Posewitz M, Seibert M, Darzins A. Microalgal triacylglycerols as feedstocks for biofuel production: perspectives and advances. Plant J. 2008;54:621-39.

19. Mortensen SH, Børsheim KY, Rainuzzo J, Knutsen G. Fatty acid and elemental composition of the marine diatom Chaetoceros gracilis Schütt. Effects of silicate deprivation, temperature and light intensity. J Exp Mar Biol Ecol. 1988;122(2):173-85.

20. Msanne J, Xu D, Konda AR, Casas-Mollano JA, Awada T, Cahoon EB, Cerutti H. Metabolic and gene expression changes triggered by nitrogen deprivation in the photoautotrophically grown microalgae Chlamydomonas reinhardtii and Coccomyxa sp. C-169. Phytochemistry. 2012;75:50-9.

21. Tornabene TG, Holzer G, Lien S, Burris N. Lipid composition of the nitrogen starved green alga Neochloris oleoabundans. Enzyme Microb Technol. 1983;5:435-40.

22. Yang ZK, Ma YH, Zheng JW, Yang WD, Liu JS, Li HY. Proteomics to reveal metabolic network shifts towards lipid accumulation following nitrogen deprivation in the diatom. J Appl Phycol. 2014;26:73-82.

23. Yang ZK, Niu YF, Ma YH, Xue J, Zhang MH, Yang WD, Liu JS, Lu SH, Guan Y, Li HY. Molecular and cellular mechanisms of neutral lipid accumulation in diatom following nitrogen deprivation. Biotechnol Biofuels. 2013;6(1):67. 
24. Vazhappilly R, Chen F. Eicosapentaenoic acid and docosahexaenoic acid production potential of microalgae and their heterotrophic growth. J Am Oil Chem Soc. 1998;75(3):393-7.

25. Rowan KS. Photosynthetic pigments of algae. Cambridge: Cambridge University Press; 1989.

26. Jeffrey SW, Vesk M. Introduction to marine phytoplankton and their pigment signatures. In: Jeffrey SW, Montoura RFC, Wright SW, editors. Phytoplankton pigments in oceanography. Paris: UNESCO Publishing; 1997. p. 37-84.

27. Porra RJ, Pfündel EE, Engel N. Metabolism and function of photosynthetic pigments. In: Jeffrey SW, Montoura RFC, Wright SW, editors. Phytoplankton pigments in oceanography. Paris: UNESCO Publishing; 1997. p. 85-126.

28. Hosokawa M, Wanezaki S, Miyauchi K, Kurihara H, Kohno H, Kawabata J, Odashima S, Takahashi K. Apoptosis inducing effect of fucoxanthin on human leukemia cell line HL-60. Food Sci Technol Res. 1999;5:243-6.

29. Kim JM, Araki S, Kim DJ, Park CB, Takasuka N, Baba-Toriyama H, Ota T, Nir Z, Khachik F, Shimidzu N, Tanaka Y, Osawa T, Uraji T, Murakoshi M, Nishino $H$, Tsuda $H$. Chemopreventive effects of carotenoids and curcumins on mouse colon carcinogenesis after 1,2-dimethylhydrazine initiation. Carcinogenesis. 1998;19(1):81-5.

30. Kotake-Nara E, Kushiro M, Zhang H, Sugawara T, Miyashita K, Nagao A Carotenoids affect proliferation of human prostate cancer cells. J Nutr. 2001;131(12):3303-6.

31. Nishino H. Cancer prevention by carotenoids. Mutat Res. 1998;402(1-2):159-63.

32. Okuzumi J, Nishino H, Murakoshi M, Iwashima A, Tanaka Y, Yamane T, Fujita Y, Takahashi T. Inhibitory effects of fucoxanthin, a natural carotenoid, on $\mathrm{N}$-myc expression and cell cycle progression in human malignant tumor cells. Cancer Lett. 1990;55(1):75-81.

33. Martin LJ. Fucoxanthin and its metabolite fucoxanthinol in cancer prevention and treatment. Mar Drugs. 2015;13:4784-98.

34. Ban A, Aikawa S, Hattori H, Sasaki H, Sampei M, Kudoh S, Fukuchi M, Satoh K, Kashino Y. Comparative analysis of photosynthetic properties in ice algae and phytoplankton inhabiting Franklin Bay, the Canadian Arctic, with those in mesophilic diatoms during CASES 03-04. Polar Biosci. 2006;19:11-28

35. Hashihama F, Umeda H, Hamada C, Kudoh S, Hirawake T, Satoh K, Fukuchi M, Kashino Y. Light acclimation states of phytoplankton in the Southern Ocean, determined using photosynthetic pigment distribution. Mar Biol. 2010;157(10):2263-78.

36. Wright SW, van den Enden RL. Phytoplankton community structure and stocks in the East Antarctic marginal ice zone (BROKE survey, January-March 1996) determined by CHEMTAX analysis of HPLC pigment signatures. Deep Sea Res Part II. 2000;47(12-13):2363-400.

37. Mori K, Ooi T, Hiraoka M, Oka N, Hamada H, Tamura M, Kusumi T. Fucoxanthin and its metabolites in edible brown algae cultivated in deep seawater. Mar Drugs. 2004;2:63-72.

38. Ishihara T, Ifuku K, Yamashita E, Fukunaga Y, Nishino Y, Miyazawa A Kashino Y, Inoue-Kashino N. Utilization of light by fucoxanthin-chlorophyll-binding protein in a marine centric diatom, Chaetoceros gracilis. Photosynth Res. 2015;126:437-47.

39. Miki W. Biological functions and activities of animal carotenoids. Pure Appl Chem. 1991;63:141-6.

40. Falkowski PG, Raven JA. Aquatic photosynthesis. 2nd ed. New Jersey: Princeton University Press; 2007.

41. Mackey MD, Mackey DJ, Higgins HW, Wright SW. CHEMTAX — a program for estimating class abundances from chemical markers: application to HPLC measurements of phytoplankton. Mar Ecol Prog Ser. 1996;144:265-83.

42. Stauber JL, Jeffrey SW. Photosynthetic pigments in fifty-one species of marine diatoms. J Phycol. 1988;24:158-72.

43. Vesk M, Jeffrey SW. Ultrastructure and pigments of two strains of the picoplanktonic alga Pelagococcus subviridis (Chrysophyceae). J Phycol. 1987;23(Issue Supplement s2):322-36.

44. Gieskes WWC, Kraay GW. Analysis of phytoplankton pigments by HPLC before, during, and after mass occurrence of the microflagellate Corymbellus aureus during the spring bloom in the open northern North Sea in 1983. Mar Biol. 1986;92:45-52

45. Fawley MW. A new form of chlorophyll $c$ involved in light-harvesting. Plant Physiol. 1989;91(2):727-32.
46. Garrido JL, Otero J, Maestro MA, Zapata M. The main nonpolar chlorophyll c from Emiliania huxleyi (Prymnesiophyceae) is a chlorophyll c2-monogalactosyldiacylglyceride ester: a mass spectrometry study. J Phycol. 2000;36:497-505.

47. Nelson JR, Wakeham SG. A phytol-substituted chlorophyll c from Emiliania huxleyi (Prymnesiophyceae). J Phycol. 1989;25:761-6.

48. Arsalane W, Rousseau B, Duval J-C. Influence of the pool size of the xanthophyll cycle on the effects of light stress in a diatom: competition between photoprotection and photoinhibition. Photochem Photobiol. 1994;60:237-43.

49. Ikeya T, Kashino Y, Kudoh S, Imura S, Watanabe K, Fukuchi M. Acclimation of photosynthetic properties in psychrophilic diatom isolates under different light intensities. Polar Biosci. 2000;13:43-54.

50. Kashino Y, Kudoh S. Concerted response of xanthophyll-cycle pigments in a marine diatom, Chaetoceros gracilis, to the sifts of light condition. Phycol Res. 2003;51(3):168-72.

51. Lohr M, Wilhelm C. Algae displaying the diadinoxanthin cycle also possess the violaxanthin cycle. Proc Natl Acad Sci USA. 1999:96(15):8784-9.

52. Olaizola M, Laroche J, Kolber Z, Falkowski PG. Non-photochemical fluorescence quenching and the diadinoxanthin cycle in a marine diatom. Photosynth Res. 1994;41:357-70.

53. Olaizola M, Yamamoto HY. Short-term response of the diadinoxanthin cycle and fluorescence yield to high irradiance in Chaetoceros muelleri (Bacillariophyceae). J Phycol. 1994;30:606-12.

54. Demmig-Adams B. Carotenoids and photoprotection in plants: a role for the xanthophyll zeaxanthin. Biochim Biophys Acta. 1990;1020(1):1-24.

55. Apt KE, Kroth-Pancic PG, Grossman AR. Stable nuclear transformation of the diatom Phaeodactylum tricornutum. Mol Gen Genet. 1996:252(5):572-9.

56. De Riso V, Raniello R, Maumus F, Rogato A, Bowler C, Falciatore A. Gene silencing in the marine diatom Phaeodactylum tricornutum. Nucleic Acids Res. 2009;37(14):e96.

57. Dunahay TG, Jarvis EE, Roessler PG. Genetic transformation of the diatoms Cyclotella cryptica and Navicula saprophila. J Phycol. 1995;31(6):1004-12.

58. Miyagawa-Yamaguchi A, Okami T, Kira N, Yamaguchi H, Ohnishi K, Adachi M. Stable nuclear transformation of the diatom Chaetoceros sp. Phycol Res. 2011:59(2):113-9.

59. Poulsen N, Kroger N. A new molecular tool for transgenic diatoms: control of mRNA and protein biosynthesis by an inducible promoterterminator cassette. FEBS J. 2005;272(13):3413-23.

60. Sakaue K, Harada H, Matsuda Y. Development of gene expression system in a marine diatom using viral promoters of a wide variety of origin. Physiol Plant. 2008;133(1):59-67.

61. Zaslavskaia LA, Lippmeier JC, Kroth PG, Grossman AR, Apt KE. Transformation of the diatom Phaeodactylum tricornutum (Bacillariophyceae) with a variety of selectable marker and reporter genes. J Phycol. 2000;36(2):379-86

62. Zaslavskaia LA, Lippmeier JC, Shih C, Ehrhardt D, Grossman AR, Apt KE. Trophic conversion of an obligate photoautotrophic organism through metabolic engineering. Science. 2001;292(5524):2073-5.

63. Trentacoste EM, Shrestha RP, Smith SR, Gle C, Hartmann AC, Hildebrand $\mathrm{M}$, Gerwick WH. Metabolic engineering of lipid catabolism increases microalgal lipid accumulation without compromising growth. Proc Natl Acad Sci USA. 2013:110(49):19748-53.

64. Xue J, Niu YF, Huang T, Yang WD, Liu JS, Li HY. Genetic improvement of the microalga Phaeodactylum tricornutum for boosting neutral lipid accumulation. Metab Eng. 2015;27:1-9.

65. Miyahara M, Aoi M, Inoue-Kashino N, Kashino Y, Ifuku K. Highly efficient transformation of the diatom Phaeodactylum tricornutum by multi-pulse electroporation. Biosci Biotechnol Biochem. 2013;77(4):874-6.

66. Armbrust EV, Berges JA, Bowler C, Green BR, Martinez D, Putnam NH, Zhou S, Allen AE, Apt KE, Bechner M, Brzezinski MA, Chaal BK, Chiovitti A, Davis AK, Demarest MS, Detter JC, Glavina T, Goodstein D, Hadi MZ, Hellsten U, Hildebrand M, Jenkins BD, Jurka J, Kapitonov VV, Kroger N, Lau WW, Lane TW, Larimer FW, Lippmeier JC, Lucas S, Medina M, Montsant A, Obornik M, Parker MS, Palenik B, Pazour GJ, Richardson PM, Rynearson TA, Saito MA, Schwartz DC, Thamatrakoln K, Valentin K, Vardi A, Wilkerson FP, Rokhsar DS. The genome of the diatom Thalassiosira pseudonana: ecology, evolution, and metabolism. Science. 2004;306(5693):79-86. 
67. Bowler C, Allen AE, Badger JH, Grimwood J, Jabbari K, Kuo A, Maheswari U, Martens C, Maumus F, Otillar RP, Rayko E, Salamov A, Vandepoele K, Beszteri B, Gruber A, Heijde M, Katinka M, MockT, Valentin K, Verret F, Berges JA, Brownlee C, Cadoret JP, Chiovitti A, Choi CJ, Coesel S, De Martino A, Detter JC, Durkin C, Falciatore A, Fournet J, Haruta M, Huysman $M J$, Jenkins $B D$, Jiroutova $K$, Jorgensen RE, Joubert $Y$, Kaplan A, Kroger $N$, Kroth PG, La Roche J, Lindquist E, Lommer M, Martin-Jezequel V, Lopez PJ, Lucas S, Mangogna M, McGinnis K, Medlin LK, Montsant A, OudotLeSecq MP, Napoli C, Obornik M, Parker MS, Petit JL, Porcel BM, Poulsen N, Robison M, Rychlewski L, Rynearson TA, Schmutz J, Shapiro H, Siaut M, Stanley M, Sussman MR, Taylor AR, Vardi A, von Dassow P, Vyverman W, Willis A, Wyrwicz LS, Rokhsar DS, Weissenbach J, Armbrust EV, Green BR, Van de Peer Y, Grigoriev IV. The Phaeodacty/um genome reveals the evolutionary history of diatom genomes. Nature. 2008;456(7219):239-44.

68. Olaizola M, Bienfang PK, Ziemann DA. Pigment analysis of phytoplankton during a Subarctic spring bloom: xanthophyll cycling. J Exp Mar Biol Ecol. 1992;158:59-74.

69. Falkowski PG, Oliver MJ. Mix and match: how climate selects phytoplankton. Nat Rev Microbiol. 2007;5(10):813-9.

70. Nhu CV. A comparison of yield and quality of the rotifer (Brachionus plicatilis_-L-strain) fed different diets under aquaculture conditions, Vietnam. Asian Fish Sci. 2004;17(4):357-63.

71. Masuda A, Kosaka S, Horaguchi K, Murakami K. High efficiency mass production of micro algae as foods for oyster seedlings. Eco-Eng. 2005;17:17-22.

72. Liang Y, Sun M, Tian C, Cao C, Li Z. Effects of salinity stress on the growth and chlorophyll fluorescence of Phaeodactylum tricornutum and Chaetoceros gracilis (Bacillariophyceae). Bot Mar. 2014;57:469-76.

73. Parrish CC, Wangersky PJ. Growth and lipid class composition of the marine diatom, Chaetoceros gracilis, in laboratory and mass culture turbidostats. J Plankton Res. 1990;12(5):1011-21.

74. Ifuku K, Yan D, Miyahara M, Inoue-Kashino N, Yamamoto YY, Kashino Y. A stable and efficient nuclear transformation system for the diatom Chaetoceros gracilis. Photosynth Res. 2015;123(2):203-11.

75. Eppley RW, Rogers JN, McCarthy JJ. Half-saturation constants for uptake of nitrate and ammonium by marine phytoplankton. Limnol Oceanogr. 1969;14:912-20

76. Goldman JC, MCCarthy JJ. Steady-state growth and ammonium uptake of a fast-growing marine diatom. Limnol Oceanogr. 1978;1978(23):695-703.

77. Parslow JS, Harrison PJ, Thompson PA. Development of rapid ammonium uptake during starvation of batch and chemostat cultures of the marine diatom Thalassiosira pseudonana. Mar Biol. 1984;83(1):43-50.

78. Guillard RR, Ryther JH. Studies of marine planktonic diatoms. I. Cyclotella nana Hustedt, and Detonula confervacea (cleve) Gran. Can J Microbiol. 1962;8:229-39.

79. Hildebrand M, Davis AK, Smith SR, Traller JC, Abbriano R. The place of diatoms in the biofuels industry. Biofuels. 2012;3(2):221-40.

80. Provasoli L, McLaughlin JJA, Droop MR. The development of artificial media for marine algae. Archiv für Mikrobiologie. 1957;25(4):392-428.

81. Durham BP, Sharma S, Luo H, Smith CB, Amin SA, Bender SJ, Dearth SP Van Mooy BA, Campagna SR, Kujawinski EB, Armbrust EV, Moran MA. Cryptic carbon and sulfur cycling between surface ocean plankton. Proc Natl Acad Sci USA. 2015;112(2):453-7.

82. Imamura $S$, Kanesaki Y, Ohnuma M, Inouye $T$, Sekine $Y$, Fujiwara T, Kuroiwa T, Tanaka K. R2R3-type MYB transcription factor, CmMYB1, is a central nitrogen assimilation regulator in Cyanidioschyzon merolae. Proc Natl Acad Sci USA. 2009:106(30):12548-53.

83. Matsuzaki M, Misumi O, Shin IT, Maruyama S, Takahara M, Miyagishima SY, Mori T, Nishida K, Yagisawa F, Nishida K, Yoshida Y, Nishimura Y, Nakao S, Kobayashi T, Momoyama Y, Higashiyama T, Minoda A, Sano M, Nomoto H, Oishi K, Hayashi H, Ohta F, Nishizaka S, Haga S, Miura S, Morishita T, Kabeya Y, Terasawa K, Suzuki Y, Ishii Y, Asakawa S, Takano H, Ohta N, Kuroiwa H, Tanaka K, Shimizu N, Sugano S, Sato N, Nozaki H, Ogasawara $\mathrm{N}$, Kohara Y, Kuroiwa T. Genome sequence of the ultrasmall unicellular red alga Cyanidioschyzon merolae 10D. Nature. 2004;428(6983):653-7.
84. Chen S-Y, Pan L-Y, Hong M-J, Lee A-C. The effects of temperature on the growth of and ammonia uptake by marine microalgae. Bot Stud. 2012;53:125-33.

85. Yongmanitchai W, Ward OP. Omega-3/6 fatty acids: alternative sources of production. Process Biochem. 1989;24:117-25.

86. Izgoren-Sunlu FS, Büyükişik B. Nutrient effects on the growth rates of marine diatom Chaetoceros gracilis Schütt. EU J Fish Aquat Sci. 2006;23:1-5.

87. Houghton JD. Heams and bilins. In: Houghton JD, Hendry GAF, editors. Natural food colorants. 2nd ed. Dordrecht: Springer; 1996. p. 157-96.

88. Hendry GAF. Chlorophylls and chlorophyll derivatives. In: Houghton JD, Hendry GAF, editors. Natural food colorants. Dordrecht: Springer; 1996. p. $131-56$.

89. Jin ES, Polle JEW, Lee HK, Hyun SM, Chang M. Xanthophylls in microalgae: from biosynthesis to biotechnological mass production and application. $J$ Microbiol Biotechnol. 2003;13:165-74.

90. Domergue F, Spiekermann P, Lerchl J, Beckmann C, Kilian O, Kroth PG, Boland W, Zahringer U, Heinz E. New insight into Phaeodactylum tricornutum fatty acid metabolism. Cloning and functional characterization of plastidial and microsomal $\triangle 12$-fatty acid desaturases. Plant Physiol. 2003:131(4):1648-60.

91. Furuya K, Hayashi M, Yabushita Y. HPLC determination of phytoplankton pigments using $\mathrm{N}, \mathrm{N}$-dimethylformamide. J Oceanogr. 1998;54(2):199-203

92. Porra RJ, Thompson WA, Kriedemann PE. Determination of accurate extinction coefficients and simultaneous equations for assaying chlorophylls $a$ and $b$ extracted with four different solvents: verification of the concentration of chlorophyll standards by atomic absorption spectroscopy. Biochim Biophys Acta. 1989;975:384-94.

93. Bligh EG, Dyer WJ. A rapid method of total lipid extraction and purification. Can J Biochem Physiol. 1959;37:911-7.

94. Matsumoto M, Sugiyama H, Maeda Y, Sato R, Tanaka T, Matsunaga T. Marine diatom, Navicula sp. strain JPCC DA0580 and marine green alga, Chlorella sp. strain NKG400014 as potential sources for biodiesel production. Appl Biochem Biotechnol. 2010;161(1-8):483-90.

95. Duong VT, Thomas-Hall SR, Schenk PM. Growth and lipid accumulation of microalgae from fluctuating brackish and sea water locations in South East Queensland-Australia. Front Plant Sci. 2015;6:359.

96. Gouveia L, Oliveira AC. Microalgae as a raw material for biofuels production. J Ind Microbiol Biotechnol. 2009;36(2):269-74.

97. Liang Y, Sarkany N, Cui Y. Biomass and lipid productivities of Chlorella vulgaris under autotrophic, heterotrophic and mixotrophic growth conditions. Biotechnol Lett. 2009;31(7):1043-9.

98. Moser BR, Vaughn SF. Evaluation of alkyl esters from Camelina sativa oil as biodiesel and as blend components in ultra low-sulfur diesel fuel. Bioresour Technol. 2010;101(2):646-53.

\section{Submit your next manuscript to BioMed Central and we will help you at every step:}

- We accept pre-submission inquiries

- Our selector tool helps you to find the most relevant journal

- We provide round the clock customer support

- Convenient online submission

- Thorough peer review

- Inclusion in PubMed and all major indexing services

- Maximum visibility for your research

Submit your manuscript at www.biomedcentral com/submit 